\title{
The Terminology of Artificial Sentience
}

Janet VT Pauketat

Sentience Institute

janet@sentienceinstitute.org

\begin{abstract}
We consider the terminology used to describe artificial entities and how this terminology may affect the moral consideration of artificial entities. Different combinations of terms variously emphasize the entity's role, material features, psychological features, and different research perspectives. ${ }^{1}$ The ideal term may vary across context, but we favor "artificial sentience" in general, in part because "artificial" is more common in relevant contexts than its near-synonyms, such as "synthetic" and "digital," and to emphasize the sentient artificial entities who deserve moral consideration. The terms used to define and refer to these entities often take a human perspective by focusing on the benefits and drawbacks to humans. Evaluating the benefits and drawbacks of the terminology to the moral consideration of artificial entities may help to clarify emerging research, improve its impact, and align the interests of sentient artificial entities with the study of artificial intelligence (AI), especially research on AI ethics.
\end{abstract}

\section{The importance of conceptual clarity}

Sentience Institute uses the term "artificial sentience" to describe artificial entities with the capacity for positive and negative experiences. When we survey the public, we use the terms "artificial beings" and "robots/AIs" to refer to "intelligent entities built by humans, such as robots, virtual copies of human brains, or computer programs that solve problems, with or without a physical body, that may exist now or in the future." We have also used the terms "artificial intelligences" and "artificial entities." These five terms are just a few of the many used in the design, development, and scholarship of AI.

When a term that expresses a concept is ambiguous, it becomes difficult to disentangle the theoretical connotation intended by the researchers and the meaning of participants' responses in empirical studies. This reduces the impact of empirical research, especially for concepts that are tied to ordinary language like "artificial."2 Researchers may assume that everyone shares their

\footnotetext{
${ }^{1}$ We consider terms and their connotations in the English language. The usage and meaning of some terms is likely to be different in other languages, a topic that requires future study. Linguistic differences may have global implications for the moral consideration of artificial entities that have yet to be examined.

2 Blascovich and Ginsburg (1978) discuss conceptual ambiguity in regards to the social psychological study of "risk-taking."
} 
same definitions when in fact they are fuzzy concepts, "[that] possess two or more alternative meanings and thus cannot be reliably identified or applied by different readers or scholars" (Markusen, 2003, p. 702). Markusen argues that this can decrease scholars' belief in the need for empirical tests, can lead to the devaluation of empirical evidence, and can reduce the credibility of research.

Conceptual ambiguity can lead to concept creep, when a concept becomes so broad and deep that non-examples are difficult to find. The methodological and real-world implications of conceptual ambiguity range from reduced trustworthiness of the research to the detachment of scholarship from policy-making and advocacy. For instance, a policy-maker is more likely to avoid "fuzzy concepts" when implementing policies because there are no clear definitions that can be used to structure their policy. That is, "fuzzy concepts" provide fuzzy guidance on how a policy will affect systemic power distributions, legal structures, and the actions of different people (e.g., advocates, politicians, lay people).

In the following sections, we attempt to include as many of the terms as we could find relevant to the interdisciplinary study of artificial entities' moral, social, and mental capacities. ${ }^{3}$

Note. We loosely group terms into four categories although several terms could belong to other categories.

\section{Terminology and conceptual definitions}

The first set of terms elicits a mental image of an entity's role in the world. These terms are most frequently used as nouns that can be modified with information about their material or psychological features, although some, like "super" and "transformative," typically serve as adjectives. "Machine" is used as a noun with feature modifiers (e.g., "digital machine," "autonomous machine"). However, it is also sometimes used as a feature-like modifier of other features (e.g., "machine intelligence"). Below are terms defining an entity's role.

\footnotetext{
${ }^{3}$ See the Appendix for a list of terms defining relevant fields of study.
} 
Table 1: Terminology defining an entity's role

\begin{tabular}{|c|c|c|c|c|}
\hline \multicolumn{5}{|c|}{ Entity's Role } \\
\hline Term & Definition(s) & Benefits & Drawbacks & Source(s) \\
\hline Agent & $\begin{array}{l}\text { an interactive, autonomous, } \\
\text { adaptable entity }\end{array}$ & $\begin{array}{l}\text { - common usage in moral } \\
\text { philosophy and moral } \\
\text { psychology } \\
\text { - clear pairing with "patient" } \\
\text { - association with specific } \\
\text { actions and intentions } \\
\text { - applies to entities of any } \\
\text { material composition }\end{array}$ & $\begin{array}{l}\text { - moral consideration of agents } \\
\text { not typically thought about } \\
\text { - common usage includes } \\
\text { multiple other associations (e.g., } \\
\text { "government agent," "publicity } \\
\text { agent") }\end{array}$ & $\underline{\text { Floridi \& Sanders, }}$ \\
\hline Being & 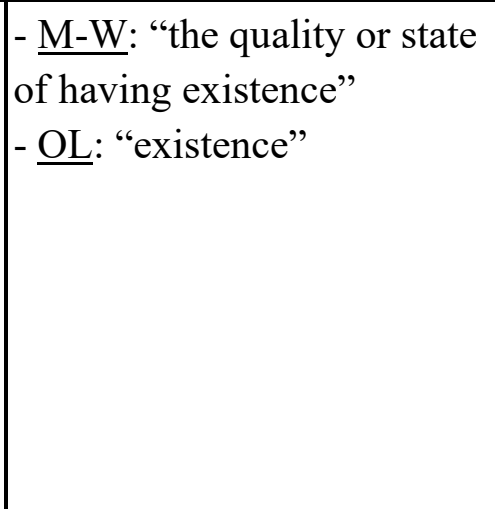 & $\begin{array}{l}\text { - accessible } \\
\text { - is concrete and brings to } \\
\text { mind a specific meaning } \\
\text { - commonly paired with } \\
\text { "human" and "living" } \\
\text { - already used to describe } \\
\text { robots } \\
\text { - avoids making worth } \\
\text { dependent on moral action }\end{array}$ & $\begin{array}{l}\text { - colloquial } \\
\text { - may activate only certain } \\
\text { conceptions of AI (e.g., has a } \\
\text { spirit, capable of advanced } \\
\text { cognition) } \\
\text { - may imply needing to have a } \\
\text { soul or metaphysical presence }\end{array}$ & $\begin{array}{l}\text { Merriam-Webster, } \\
\frac{2021}{\text { Languages, } 2021}\end{array}$ \\
\hline Beneficiary & $\begin{array}{l}\text { derives well-being from } \\
\text { resources }\end{array}$ & $\begin{array}{l}\text { - clear connection to moral } \\
\text { consideration } \\
\text { - implies worthiness or social } \\
\text { value }\end{array}$ & $\begin{array}{l}\text { - limited usage in research } \\
\text { - possible negative connotations } \\
\text { (e.g., "welfare recipient" } \\
\text { amongst humans) }\end{array}$ & $\begin{array}{l}\text { Shulman \& } \\
\text { Bostrom, 2021 }\end{array}$ \\
\hline
\end{tabular}




\begin{tabular}{|c|c|c|c|c|}
\hline & & $\begin{array}{l}\text { - grants social status in } \\
\text { human society }\end{array}$ & $\begin{array}{l}\text { - possibly threatening to humans } \\
\text { because of implied resource } \\
\text { sharing }\end{array}$ & \\
\hline Device & $\begin{array}{l}\text { "a thing made or adapted for } \\
\text { a particular purpose, } \\
\text { especially a piece of } \\
\text { mechanical or electronic } \\
\text { equipment" }\end{array}$ & $\begin{array}{l}\text { - enables discussion of } \\
\text { mechanical or electronic safe } \\
\text { and accurate functioning } \\
\text { - easy to bring examples to } \\
\text { mind (e.g., "toaster," "coffee } \\
\text { maker," "vacuum") }\end{array}$ & $\begin{array}{l}\text { - strong association with tool } \\
\text { use (e.g., "consumer device," } \\
\text { "ttechnical device," } \\
\text { "ttechnological device," "smart } \\
\text { device") } \\
\text { - strong association with lack of } \\
\text { agency }\end{array}$ & $\begin{array}{l}\text { Oxford } \\
\text { Languages, } 2021\end{array}$ \\
\hline Entity & $\begin{array}{l}\text { "a thing with distinct and } \\
\text { independent existence" }\end{array}$ & $\begin{array}{l}\text { - commonly used to refer to } \\
\text { robots, AIs, and nonhuman } \\
\text { animals } \\
\text { - synonymous with "being" } \\
\text { and "living" } \\
\text { - does not require biological } \\
\text { life } \\
\text { - does not require a soul or } \\
\text { metaphysical presence }\end{array}$ & $\begin{array}{l}\text { - could refer to an individual, a } \\
\text { group of individuals, or a } \\
\text { corporation } \\
\text { - abstract and difficult to } \\
\text { mentally picture } \\
\text { - may prompt objectification } \\
\text { - can imply alienness }\end{array}$ & $\begin{array}{l}\text { Oxford } \\
\text { Languages, } 2021\end{array}$ \\
\hline Life & $\begin{array}{l}\text { "the condition that } \\
\text { distinguishes animals and } \\
\text { plants from inorganic matter, } \\
\text { including the capacity for } \\
\text { growth, reproduction, } \\
\text { functional activity, and } \\
\text { continual change preceding } \\
\text { death" }\end{array}$ & $\begin{array}{l}\text { - enables attribution of } \\
\text { qualities typically reserved } \\
\text { for biological, material } \\
\text { entities } \\
\text { - compatible with the "think, } \\
\text { sense, act" robotics paradigm }\end{array}$ & $\begin{array}{l}\text { - definition based on qualities of } \\
\text { biological entities } \\
\text { - may activate only certain } \\
\text { conceptions of AI (e.g., has a } \\
\text { spirit, capable of advanced } \\
\text { cognition, derived from } \\
\text { biological processes) } \\
\text { - implies death or a permanent } \\
\text { end-state }\end{array}$ & $\begin{array}{l}\text { Oxford } \\
\text { Languages, } 2021\end{array}$ \\
\hline
\end{tabular}




\begin{tabular}{|c|c|c|c|c|}
\hline Machine & $\begin{array}{l}\text { "aan apparatus using or } \\
\text { applying mechanical power } \\
\text { and having several parts, each } \\
\text { with a definite function and } \\
\text { together performing a } \\
\text { particular task" }\end{array}$ & $\begin{array}{l}\text { - intended to apply to non- } \\
\text { biological, constructed } \\
\text { entities } \\
\text { - implies complex } \\
\text { composition and integration } \\
\text { of cooperative internal } \\
\text { systems }\end{array}$ & $\begin{array}{l}\text { - common association with } \\
\text { instrumental tool use } \\
\text { - not necessarily digital or } \\
\text { electronic (e.g., a tractor) } \\
\text { - dissociated with experiential } \\
\text { and affective capacities } \\
\text { - denies possibility for human- } \\
\text { like internal states (e.g., } \\
\text { mechanistic dehumanization, } \\
\text { "automatons") } \\
\text { - common association with } \\
\text { being rigid, cold, or inflexible }\end{array}$ & $\begin{array}{l}\text { Oxford } \\
\text { Languages, } 2021\end{array}$ \\
\hline Patient & $\begin{array}{l}\text { an entity who is acted on or } \\
\text { responds to an action }\end{array}$ & $\begin{array}{l}\text { - common usage in moral } \\
\text { philosophy and moral } \\
\text { psychology } \\
\text { - clear pairing with "agent" } \\
\text { - implies need for moral } \\
\text { consideration }\end{array}$ & $\begin{array}{l}\text { - strong association with field of } \\
\text { medicine } \\
\text { - could imply weakness or need } \\
\text { for treatment due to medical } \\
\text { association } \\
\text { - may be more commonly } \\
\text { associated with humans than } \\
\text { other entities }\end{array}$ & $\underline{\text { Floridi \& Sanders, }}$ \\
\hline $\begin{array}{l}\text { Person ("legal } \\
\text { person") }\end{array}$ & $\begin{array}{l}\text { - person: "a human being } \\
\text { regarded as an individual" } \\
\text { - legal person: "an individual, } \\
\text { company, or other entity } \\
\text { which has legal rights and is } \\
\text { subject to obligations" }\end{array}$ & $\begin{array}{l}\text { - grants human-like status } \\
\text { - may encourage support for } \\
\text { AI rights } \\
\text { - could be easily applied in } \\
\text { virtual or digital worlds } \\
\text { - can be applied to } \\
\text { distinguishing individuals }\end{array}$ & $\begin{array}{l}\text { - philosophical arguments } \\
\text { against the term applied to } \\
\text { artificial entities (e.g., Bryson, } \\
\underline{2010} \text { ) } \\
\text { - strong association with } \\
\text { conceptions of what it means to } \\
\text { be a biological, corporeal human } \\
\text { - may interrupt advocacy for the }\end{array}$ & $\begin{array}{l}\text { Oxford } \\
\text { Languages, } 2021\end{array}$ \\
\hline
\end{tabular}




\begin{tabular}{|c|c|c|c|c|}
\hline & & & $\begin{array}{l}\text { legal personhood of nonhuman } \\
\text { animals (e.g., Nonhuman Rights } \\
\text { Project) }\end{array}$ & \\
\hline Robot & $\begin{array}{l}\text { "machines using a sense, } \\
\text { think, act paradigm to gather } \\
\text { data about the environment, } \\
\text { process the data } \\
\text { autonomously, and act upon } \\
\text { the world" }\end{array}$ & $\begin{array}{l}\text { - well-established and } \\
\text { commonly used } \\
\text { - incorporates perceptual, } \\
\text { cognitive, and behavioral } \\
\text { capacities } \\
\text { - applicable in many contexts } \\
\text { (e.g., social, industrial) } \\
\text { - arguments exist for the } \\
\text { consideration of robot rights } \\
\text { and duties }\end{array}$ & $\begin{array}{l}\text { - requires a material body } \\
\text { - moral consideration discussed } \\
\text { primarily in relation to some } \\
\text { sub-types (e.g., "social robots") } \\
\text { - common association with } \\
\text { instrumental uses (e.g., cleaning, } \\
\text { factory production) } \\
\text { - common association with } \\
\text { being rigid, cold, or inflexible }\end{array}$ & Gunkel, 2018 \\
\hline "Super" & $\begin{array}{l}\text { - OL: "especially; } \\
\text { particularly" } \\
\text { - Bostrom: far better or more } \\
\text { advanced than a human }\end{array}$ & $\begin{array}{l}\text { - used in common parlance } \\
\text { - can be easily understood as } \\
\text { a noun or verb modifier }\end{array}$ & $\begin{array}{l}\text { - different meanings depending } \\
\text { on context } \\
\text { - possibly threatening to human } \\
\text { uniqueness } \\
\text { - limited usage across } \\
\text { disciplines } \\
\text { - implies a linear and } \\
\text { hierarchical progression of } \\
\text { capacities rather than a possible } \\
\text { equivalency of capacities }\end{array}$ & $\begin{array}{l}\text { Bostrom, 1998; } \\
\text { Oxford } \\
\text { Languages, } 2021\end{array}$ \\
\hline System & $\begin{array}{l}\text { "a set of things working } \\
\text { together as parts of a } \\
\text { mechanism or an } \\
\text { interconnecting network" }\end{array}$ & $\begin{array}{l}\text { - implies complex, dynamic, } \\
\text { and integrated components } \\
\text { that may promote moral } \\
\text { consideration } \\
\text { - does not require a material }\end{array}$ & $\begin{array}{l}\text { - dissociated with experiential } \\
\text { and affective capacities } \\
\text { - not typically associated with } \\
\text { moral consideration } \\
\text { - can indicate intraindividual }\end{array}$ & $\begin{array}{l}\text { Oxford } \\
\text { Languages, } 2021\end{array}$ \\
\hline
\end{tabular}




\begin{tabular}{|l|l|l|l|l|}
\hline & & $\begin{array}{l}\text { body } \\
\text { - offers a holistic image of a } \\
\text { complex entity }\end{array}$ & components or multiple entities \\
\hline Target & $\begin{array}{l}\text { "an area or object that is the } \\
\text { focus of a process, inquiry, or } \\
\text { activity" }\end{array}$ & $\begin{array}{l}\text { - implies a recipient who } \\
\text { could receive moral } \\
\text { consideration } \\
\text { - no valence }\end{array}$ & $\begin{array}{l}\text { - nebulous applications and } \\
\text { associations (e.g., the } \\
\text { superstore, for an arrow, of } \\
\text { social derision or lauding) } \\
\text { - directionality may preclude } \\
\text { conceptions of relationality }\end{array}$ & $\begin{array}{l}\text { American } \\
\text { Psychological }\end{array}$ \\
\hline Transformative & $\begin{array}{l}\text { "causing a marked change in } \\
\text { someone or something" }\end{array}$ & $\begin{array}{l}\text { - sounds positive } \\
\text { - implies a changing outlook } \\
\text { or world that might enable } \\
\text { moral consideration } \\
\text { - implies advanced features } \\
\text { that may enable moral } \\
\text { consideration }\end{array}$ & $\begin{array}{l}\text { - not typically associated with } \\
\text { moral consideration } \\
\text { - not typically associated with } \\
\text { agentic, cognitive or } \\
\text { experiential, affective capacities } \\
\text { - may be more referential to an } \\
\text { abstract system or state rather } \\
\text { than an entity or individual } \\
\text { - may be focused on effects on } \\
\text { humans }\end{array}$ & $\begin{array}{l}\text { Oxanguages, 2021 } \\
\text { Land }\end{array}$ \\
\hline
\end{tabular}


The second set of terms evokes a mental image of an artificial entity's material structure. These terms focus either on what the entity is made from or how they exist. They often modify terms defining an entity's role (e.g., "artificial agent"). Below are terms defining material features. 
Table 2: Terminology defining material features

\begin{tabular}{|c|c|c|c|c|}
\hline \multicolumn{5}{|c|}{ Material Features } \\
\hline Term & Definition(s) & Benefits & Drawbacks & Source(s) \\
\hline Artificial & $\begin{array}{l}\text { "made or produced by human } \\
\text { beings rather than occurring } \\
\text { naturally, especially as a copy } \\
\text { of something natural" }\end{array}$ & $\begin{array}{l}\text { - intended to apply to } \\
\text { constructed phenomena } \\
\text { - well-known and widely used } \\
\text { - allows for a broad set of } \\
\text { possible features and material } \\
\text { composition } \\
\text { - distinguishes between } \\
\text { biological or natural and non- } \\
\text { biological or unnatural } \\
\text { - can be used to refer to partly } \\
\text { non-biological and partly } \\
\text { biological phenomena }\end{array}$ & $\begin{array}{l}\text { - alternate meaning may imply } \\
\text { "fakeness" } \\
\text { - may imply a dichotomy of } \\
\text { value for natural and unnatural } \\
\text { - may imply a filial or } \\
\text { "paternal" relationship to } \\
\text { humans } \\
\text { - may convey status benefits to } \\
\text { the constructors (e.g., for the } \\
\text { prowess of invention) without } \\
\text { parallel benefits for the } \\
\text { constructed }\end{array}$ & $\begin{array}{l}\text { Oxford Languages, } \\
2021 \\
\end{array}$ \\
\hline Cyber & $\begin{array}{l}\text { "relating to or characteristic of } \\
\text { the culture of computers, } \\
\text { information technology, and } \\
\text { virtual reality" }\end{array}$ & $\begin{array}{l}\text { - embodiment not required } \\
\text { - emphasis on computers, } \\
\text { information, and virtual reality } \\
\text { rather than on humans }\end{array}$ & $\begin{array}{l}\text { - less commonly used } \\
\text { - some associations may be } \\
\text { negative (e.g., } \\
\text { "cybersecurity," } \\
\text { "cyberwarfare") } \\
\text { - may sound outdated to } \\
\text { experts and the general public }\end{array}$ & $\begin{array}{l}\text { Oxford Languages, } \\
2021\end{array}$ \\
\hline Digital & $\begin{array}{l}\text { “( of signals or data) expressed } \\
\text { as series of the digits } 0 \text { and } 1 \text {, } \\
\text { typically represented by values }\end{array}$ & $\begin{array}{l}\text { - intended to apply to non- } \\
\text { biological phenomena } \\
\text { - illustrative of computer }\end{array}$ & $\begin{array}{l}\text { - not considerate of } \\
\text { embodiment } \\
\text { - implies "cold cognition," }\end{array}$ & $\begin{array}{l}\text { Oxford Languages, } \\
2021\end{array}$ \\
\hline
\end{tabular}




\begin{tabular}{|c|c|c|c|c|}
\hline & $\begin{array}{l}\text { of a physical quantity such as } \\
\text { voltage or magnetic } \\
\text { polarization" }\end{array}$ & $\begin{array}{l}\text { programs and algorithms } \\
\text { - does not require embodiment }\end{array}$ & $\begin{array}{l}\text { mechanical properties, and } \\
\text { automation } \\
\text { - lower similarity to } \\
\text { "humanness" may limit moral } \\
\text { consideration }\end{array}$ & \\
\hline Electronic & $\begin{array}{l}\text { "(of a device) having or } \\
\text { operating with the aid of many } \\
\text { small components, especially } \\
\text { microchips and transistors, that } \\
\text { control and direct an electric } \\
\text { current" }\end{array}$ & $\begin{array}{l}\text { - intended to apply to non- } \\
\text { biological phenomena } \\
\text { - illustrative of technology }\end{array}$ & $\begin{array}{l}\text { - close association with tools } \\
\text { like clocks or game consoles } \\
\text { may limit moral consideration } \\
\text { - implies a material structure } \\
\text { or composition }\end{array}$ & $\begin{array}{l}\text { Oxford Languages, } \\
2021\end{array}$ \\
\hline Embodied & $\begin{array}{l}\text { - Körner et al.: "the body, its } \\
\text { sensorimotor state, its } \\
\text { morphology, or its mental } \\
\text { representation play an } \\
\text { instrumental role in information } \\
\text { processing" } \\
\text { - OL: "provide (a spirit) with a } \\
\text { physical form" }\end{array}$ & $\begin{array}{l}\text { - applicable to various entities } \\
\text { - includes mental and physical } \\
\text { states, feedback between the } \\
\text { two, and both perceptual and } \\
\text { cognitive sources of } \\
\text { information } \\
\text { - higher similarity to } \\
\text { "humanness" may increase } \\
\text { moral consideration }\end{array}$ & $\begin{array}{l}\text { - requires a material container } \\
\text { or body } \\
\text { - does not distinguish material } \\
\text { composition } \\
\text { - relationship to entity's role is } \\
\text { unclear } \\
\text { - difficult and sometimes } \\
\text { nonsensical to pair with } \\
\text { psychological features } \\
\text { - may imply a dichotomy of } \\
\text { value for embodied } \\
\text { and non-embodied entities }\end{array}$ & $\begin{array}{l}\text { Körner et al., 2015; } \\
\text { Oxford Languages, } \\
2021\end{array}$ \\
\hline Non-biological & $\begin{array}{l}\text { "not involving or derived from } \\
\text { biology or living organisms" }\end{array}$ & $\begin{array}{l}\text { - differentiates entities } \\
\text { traditionally labelled as } \\
\text { "living" from those } \\
\text { traditionally labelled as "non- } \\
\text { living" }\end{array}$ & $\begin{array}{l}\text { - defined in relation to } \\
\text { biological entities } \\
\text { - potentially meaningless in } \\
\text { systems or worlds without any } \\
\text { "biological" components }\end{array}$ & $\begin{array}{l}\text { Oxford Languages, } \\
2021\end{array}$ \\
\hline
\end{tabular}




\begin{tabular}{|c|c|c|c|c|}
\hline & & $\begin{array}{l}\text { - removes the value judgment } \\
\text { of "living" } \\
\text { - not considered "fake" or } \\
\text { "unnatural" } \\
\text { - allows for a broad set of } \\
\text { possible features and material } \\
\text { composition } \\
\text { - distinguishes between } \\
\text { biological or natural and non- } \\
\text { biological or unnatural }\end{array}$ & $\begin{array}{l}\text { - may preclude conceptions of } \\
\text { hybrid biological and non- } \\
\text { biological systems } \\
\text { - difficult to apply to artificial } \\
\text { entities derived from } \\
\text { evolutionarily biological } \\
\text { processes (e.g., whole brain } \\
\text { emulations) } \\
\text { - may be problematic in future } \\
\text { scenarios with non-carbon- } \\
\text { based biological lifeforms }\end{array}$ & \\
\hline Synthetic & $\begin{array}{l}\text { “(of a substance) made by } \\
\text { chemical synthesis, especially } \\
\text { to imitate a natural product” }\end{array}$ & $\begin{array}{l}\text { - distinctly non-natural or non- } \\
\text { biological }\end{array}$ & $\begin{array}{l}\text { - defined in relation to } \\
\text { "naturalness" } \\
\text { - may imply "fakeness" } \\
\text { - subject to value judgments } \\
\text { about "naturalness" and } \\
\text { "fakeness" }\end{array}$ & $\begin{array}{l}\text { Oxford Languages, } \\
2021\end{array}$ \\
\hline Virtual & $\begin{array}{l}\text { - "not physically existing as } \\
\text { such but made by software to } \\
\text { appear to do so" } \\
\text { - "almost or nearly as } \\
\text { described, but not completely } \\
\text { or according to strict } \\
\text { definition" }\end{array}$ & $\begin{array}{l}\text { - does not require a specific } \\
\text { material composition or } \\
\text { embodiment } \\
\text { - is commonly used and } \\
\text { understood } \\
\text { - is associated with conceptions } \\
\text { of digital worlds or spaces }\end{array}$ & $\begin{array}{l}\text { - exclusive of entities with a } \\
\text { material body } \\
\text { - may prompt people to think } \\
\text { only of entities living in } \\
\text { virtual environments that are } \\
\text { less accessible and routinely } \\
\text { salient (at least in the near- } \\
\text { term) } \\
\text { - can have multiple meanings } \\
\text { that have different } \\
\text { implications for moral }\end{array}$ & $\begin{array}{l}\text { Oxford Languages, } \\
2021\end{array}$ \\
\hline
\end{tabular}




\begin{tabular}{|l|l|l|l|}
\hline & & $\begin{array}{l}\text { consideration } \\
\text { - is abstract and may make it } \\
\text { difficult to form a concrete } \\
\text { mental image of what it means } \\
\text { - not distinctly nonhuman } \\
\text { - subject to value judgments } \\
\text { about the nature of reality and } \\
\text { "fakeness" }\end{array}$ \\
\hline
\end{tabular}


A third set of terms defines the psychological features of an entity. These terms operationalize abstract and indirectly observable mental phenomena (e.g., intelligence, friendliness). Psychological features are inferred from observing complex criteria agreed upon by experts. For example, we cannot observe "autonomy" directly. We infer "autonomy" from introspection (i.e., self-reports) and behavior. These terms differ from material features because material features can be directly observed. Below are terms defining psychological features. 
Table 3: Terminology defining psychological features

\begin{tabular}{|c|c|c|c|c|}
\hline \multicolumn{5}{|c|}{ Psychological Features } \\
\hline Term & Definition(s) & Benefits & Drawbacks & Source(s) \\
\hline Autonomy & $\begin{array}{l}\text { - Darling: "the ability to 'make } \\
\text { (limited) decisions about what } \\
\text { behaviors to execute based on } \\
\text { perceptions and internal states, } \\
\text { rather than following a pre- } \\
\text { determined action sequence } \\
\text { based on pre-programmed } \\
\text { commands"” } \\
\text { - F\&S: "perform internal } \\
\text { transitions to change its state" } \\
\text { - Keller: "self-government and } \\
\text { responsible control for one's } \\
\text { life" } \\
\text { - M\&R: "sense of volition and } \\
\text { internal perceived locus of } \\
\text { causality in one's } \\
\text { undertakings...actions emanate } \\
\text { from the self and reflect who } \\
\text { one really is, instead of being } \\
\text { the result of external pressures" }\end{array}$ & $\begin{array}{l}\text { - implies independent, } \\
\text { individual capacities } \\
\text { - connected with morality } \\
\text { - has been important for } \\
\text { establishing criteria for } \\
\text { understanding well-being and } \\
\text { welfare in human and } \\
\text { nonhuman animals } \\
\text { - contrast with "heteronomy," } \\
\text { or actions occurring because } \\
\text { of external demands, may } \\
\text { increase moral consideration } \\
\text { and belief that coercion of } \\
\text { artificial entities is wrong }\end{array}$ & $\begin{array}{l}\text { - relationship to moral } \\
\text { agency and patiency is } \\
\text { unclear } \\
\text { - unclear how cognitive } \\
\text { (agentic) and affective } \\
\text { (experiential) capacities } \\
\text { relate to autonomy } \\
\text { - sometimes used to refer to } \\
\text { "human-less" control } \\
\text { without requiring fully non- } \\
\text { pre-programmed sequences } \\
\text { or internally derived } \\
\text { motivation and behavior }\end{array}$ & $\begin{array}{l}\text { Darling, 2016; } \\
\text { Floridi \& Sanders, } \\
\frac{\text { 2004; Keller, 2016; }}{2018} \\
\frac{\text { Martela \& Riekki, }}{2018}\end{array}$ \\
\hline $\begin{array}{l}\text { Consciousness } \\
\text { ("subjective,", }\end{array}$ & $\begin{array}{l}\text { - Block: "the phenomenally } \\
\text { conscious aspect of a state is }\end{array}$ & $\begin{array}{l}\text { - long tradition of scholarship } \\
\text { - well-known }\end{array}$ & $\begin{array}{l}\text { - multitude of definitions } \\
\text { reduces clarity when the }\end{array}$ & $\begin{array}{l}\text { Block, 1995; } \\
\text { Muehlhauser, 2017; }\end{array}$ \\
\hline
\end{tabular}




\begin{tabular}{|c|c|c|c|c|}
\hline $\begin{array}{l}\text { “"phenomenal,” } \\
\text { “access”) }\end{array}$ & $\begin{array}{l}\text { what it is like to be in that state. } \\
\text { The mark of access- } \\
\text { consciousness, by contrast, is } \\
\text { availability for use in reasoning } \\
\text { and rationally guiding speech } \\
\text { and action." } \\
\text { - Muehlhauser: subjective } \\
\text { experience } \\
\text { - } \text { SEP: } 6 \text { possible senses of } \\
\text { consciousness (sentience, } \\
\text { wakefulness, self- } \\
\text { consciousness, "what it is like," } \\
\text { conscious states, transitive } \\
\text { consciousness); } 6 \text { possible states } \\
\text { of consciousness (mental state } \\
\text { awareness, } \\
\text { qualitative/experiential states, } \\
\text { phenomenal states, "what it is } \\
\text { like," access, narrative) }\end{array}$ & $\begin{array}{l}\text { - focuses on describing the } \\
\text { internal processes and } \\
\text { experiences of an entity }\end{array}$ & $\begin{array}{l}\text { term is used } \\
\text { - lacking scholarly } \\
\text { consensus on what it is and } \\
\text { where it comes from } \\
\text { - difficult to observe and } \\
\text { verify from a first person } \\
\text { perspective } \\
\text { - may be controversial with } \\
\text { the general public when } \\
\text { applied to artificial entities }\end{array}$ & $\begin{array}{l}\text { Stanford } \\
\text { Encyclopedia of } \\
\text { Philosophy, 2014 } \\
\end{array}$ \\
\hline Ethical & $\begin{array}{l}\text { - OL: "Relating to moral } \\
\text { principles or the branch of } \\
\text { knowledge dealing with these" } \\
\text { - Velasquez et al.: "based on } \\
\text { well-founded standards of right } \\
\text { and wrong that prescribe what } \\
\text { humans ought to do, usually in } \\
\text { terms of rights, obligations, } \\
\text { benefits to society, fairness, or }\end{array}$ & $\begin{array}{l}\text { - clearly related to morality } \\
\text { - can be applied to conceptions } \\
\text { of agency and patiency } \\
\text { - can be used when describing } \\
\text { the safe functioning of } \\
\text { artificial entities } \\
\text { - synonymous with "moral" }\end{array}$ & $\begin{array}{l}\text { - meaning depends on social } \\
\text { and cultural context } \\
\text { - complicated philosophical } \\
\text { underpinnings } \\
\text { - more often used to describe } \\
\text { artificial entities with moral } \\
\text { agency than moral patiency }\end{array}$ & $\begin{array}{l}\text { Oxford Languages, } \\
2021 \text {; Velasquez et } \\
\underline{\text { al., } 2010}\end{array}$ \\
\hline
\end{tabular}




\begin{tabular}{|c|c|c|c|c|}
\hline & specific virtues" & & & \\
\hline Friendly & $\begin{array}{l}\text { - F\&P: "include behavior that } \\
\text { displays sincere well-wishing, } \\
\text { the intrinsic valuing of the } \\
\text { other, the commitment to } \\
\text { honesty, loyalty and other } \\
\text { shared values" } \\
\text { - Reisman: " "friendliness' refers } \\
\text { to a set of behaviors, such as } \\
\text { seeking the company of others, } \\
\text { smiling, greeting, rewarding, } \\
\text { sharing, cooperation" }\end{array}$ & $\begin{array}{l}\text { - expresses desirable, safety- } \\
\text { oriented behavior } \\
\text { - focuses on relationality }\end{array}$ & $\begin{array}{l}\text { - context specific } \\
\text { - only applies to one } \\
\text { dimension of behavior and } \\
\text { relationality } \\
\text { - meaning may be likely to } \\
\text { change over time }\end{array}$ & $\begin{array}{l}\text { Fröding \& Peterson, } \\
\text { 2020; Reisman, } 1984\end{array}$ \\
\hline Intellect & $\begin{array}{l}\text { "an individual's capacity for } \\
\text { abstract, objective reasoning, } \\
\text { especially as contrasted with his } \\
\text { or her capacity for feeling, } \\
\text { imagining, or acting" }\end{array}$ & $\begin{array}{l}\text { - understood as an aspect of } \\
\text { intelligence } \\
\text { - indicates "smartness" or } \\
\text { "wit" } \\
\text { - a dimension of "mind" }\end{array}$ & $\begin{array}{l}\text { - cognitive only and thus } \\
\text { may apply primarily to } \\
\text { perceptions of agency } \\
\text { - association with } \\
\text { "intelligence" may make } \\
\text { redundant or useful only in } \\
\text { some contexts }\end{array}$ & $\begin{array}{l}\frac{\text { American }}{\text { Psychological }} \\
\text { Association, 2021 } \\
\end{array}$ \\
\hline $\begin{array}{l}\text { Intelligence } \\
\text { ("general," } \\
\text { "fluid," } \\
\text { "crystallized," } \\
\text { "visual-spatial } \\
\text { reasoning," }\end{array}$ & $\begin{array}{l}\text { - Hunt: "Fluid intelligence is the } \\
\text { ability to develop techniques for } \\
\text { solving problems that are new } \\
\text { and unusual, from the } \\
\text { perspective of the problem } \\
\text { solver. Crystallized intelligence }\end{array}$ & $\begin{array}{l}\text { - long tradition of scholarship } \\
\text { - well-known } \\
\text { - already used extensively } \\
\text { with artificial entities }\end{array}$ & $\begin{array}{l}\text { - multitude of definitions } \\
\text { reduces its conceptual clarity } \\
\text { - lacking scholarly } \\
\text { consensus on what it is and } \\
\text { where it comes from } \\
\text { - often intentionally }\end{array}$ & $\begin{array}{l}\text { Hunt, 1995; } \\
\text { Muehlhauser, 2013; } \\
\text { Sternberg, 1986; } \\
\text { Weiss et al., 2019 }\end{array}$ \\
\hline
\end{tabular}




\begin{tabular}{|c|c|c|}
\hline $\begin{array}{l}\text { "triarchic," "an } \\
\text { agent's power to } \\
\text { optimize the } \\
\text { world according } \\
\text { to its } \\
\text { preferences" }\end{array}$ & $\begin{array}{l}\text { is the ability to bring previously } \\
\text { acquired, often culturally } \\
\text { defined, problem-solving } \\
\text { methods to bear on the current } \\
\text { problem. Visual-spatial } \\
\text { reasoning is a somewhat } \\
\text { specialized ability to use visual } \\
\text { images and visual relationships } \\
\text { in problem solving" } \\
\text { - Muehlhauser: "'optimization } \\
\text { power' concept of } \\
\text { intelligence... an agent's power } \\
\text { to optimize the world according } \\
\text { to its preferences" } \\
\text { - Sternberg: a three part theory } \\
\text { of intelligence consisting of } \\
\text { internal mechanisms (for } \\
\text { learning, planning, doing), } \\
\text { dealing with novelty and } \\
\text { automation, and external } \\
\text { behavior guidance based on } \\
\text { adaptation, selection, and } \\
\text { shaping processes } \\
\text { - Weiss et al.: "General } \\
\text { intelligence is the fluid ability to } \\
\text { integrate multiple cognitive } \\
\text { abilities in the service of solving } \\
\text { a novel problem and thereby } \\
\text { accumulating crystalized }\end{array}$ & $\begin{array}{l}\text { dissociated by experts from } \\
\text { experiential capacities like } \\
\text { emotion, sentience, and } \\
\text { consciousness } \\
\text { - often thought of with } \\
\text { human-like intelligence as } \\
\text { the standard }\end{array}$ \\
\hline
\end{tabular}




\begin{tabular}{|c|c|c|c|c|}
\hline & $\begin{array}{l}\text { knowledge that, in turn, } \\
\text { facilitates further higher-level } \\
\text { reasoning." }\end{array}$ & & & \\
\hline Mind & $\begin{array}{l}\text { “....all intellectual and } \\
\text { psychological phenomena of an } \\
\text { organism, encompassing } \\
\text { motivational, affective, } \\
\text { behavioral, perceptual, and } \\
\text { cognitive systems; that is, the } \\
\text { organized totality of an } \\
\text { organism's mental and psychic } \\
\text { processes and the structural and } \\
\text { functional cognitive } \\
\text { components on which they } \\
\text { depend. The term, however, is } \\
\text { also used more narrowly to } \\
\text { denote only cognitive activities } \\
\text { and functions, such as } \\
\text { perceiving, attending, thinking, } \\
\text { problem solving, language, } \\
\text { learning, and memory.” }\end{array}$ & $\begin{array}{l}\text { - implies all non-material } \\
\text { aspects of a complex system } \\
\text { instantiated in a material } \\
\text { structure } \\
\text { - implied connection with } \\
\text { biological life may enable } \\
\text { moral consideration } \\
\text { - common interdisciplinary } \\
\text { use and understanding } \\
\text { - can apply to entities with a } \\
\text { central processing unit } \\
\text { instantiated on any material }\end{array}$ & $\begin{array}{l}\text { - sometimes used to signify } \\
\text { only "cold" cognitive } \\
\text { processes like rationality, } \\
\text { memory, and reason rather } \\
\text { than "hot" cognitive } \\
\text { processes related to } \\
\text { motivation and emotion } \\
\text { - weak link with moral } \\
\text { consideration } \\
\text { - existence of mind } \\
\text { sometimes conflated with } \\
\text { existence of consciousness }\end{array}$ & $\begin{array}{l}\frac{\text { American }}{\text { Psychological }} \\
\text { Association, 2021 } \\
\end{array}$ \\
\hline Moral & $\begin{array}{l}\text { "a code of conduct that would } \\
\text { be accepted by anyone who } \\
\text { meets certain intellectual and } \\
\text { volitional conditions, almost } \\
\text { always including the condition } \\
\text { of being rational" }\end{array}$ & $\begin{array}{l}\text { - clearly related to morality } \\
\text { - can be applied to conceptions } \\
\text { of agency and patiency } \\
\text { - synonymous with "ethical" }\end{array}$ & $\begin{array}{l}\text { - depends on social and } \\
\text { cultural context } \\
\text { - complicated philosophical } \\
\text { underpinnings } \\
\text { - more often used to describe } \\
\text { artificial entities with moral } \\
\text { agency than moral patiency }\end{array}$ & $\begin{array}{l}\frac{\text { Stanford }}{\text { Encyclopedia of }} \\
\text { Philosophy, 2020 } \\
\end{array}$ \\
\hline
\end{tabular}




\begin{tabular}{|c|c|c|c|c|}
\hline Qualia & $\begin{array}{l}\text { "the introspectively accessible, } \\
\text { phenomenal aspects of our } \\
\text { mental lives" }\end{array}$ & $\begin{array}{l}\text { - focuses on describing the } \\
\text { internal processes of an entity } \\
\text { - points to experiential } \\
\text { capacities }\end{array}$ & $\begin{array}{l}\text { - referential to } \\
\text { "consciousness" } \\
\text { - uncommon usage } \\
\text { - limited interdisciplinary } \\
\text { usage } \\
\text { - comprised of many sub- } \\
\text { components (e.g., thoughts, } \\
\text { feelings) that may reduce its } \\
\text { conceptual clarity } \\
\text { - difficult to observe and } \\
\text { verify from a first person } \\
\text { perspective }\end{array}$ & $\begin{array}{l}\frac{\text { Stanford }}{\text { Encyclopedia of }} \\
\text { Philosophy, 2017 } \\
\end{array}$ \\
\hline Sentience & 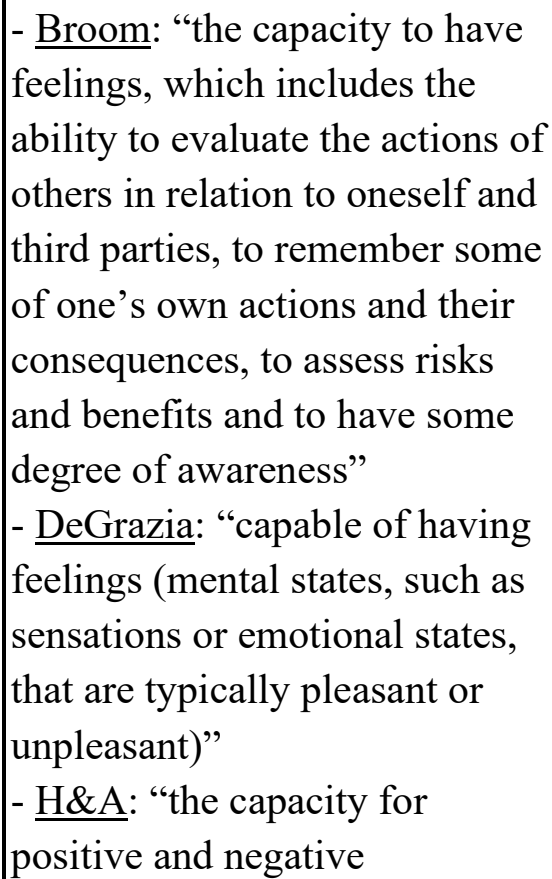 & $\begin{array}{l}\text { - centers experiential } \\
\text { capacities } \\
\text { - highlights valence of } \\
\text { experiences } \\
\text { - highlights affective } \\
\text { capacities } \\
\text { - implies worthiness of moral } \\
\text { consideration } \\
\text { - may be indicated by certain } \\
\text { third person perspective } \\
\text { observable features }\end{array}$ & $\begin{array}{l}\text { - overlap with some theories } \\
\text { and definitions of } \\
\text { consciousness } \\
\text { - possible conflation with } \\
\text { "consciousness," especially } \\
\text { amongst members of the } \\
\text { general public } \\
\text {-possible conflation with } \\
\text { "sapience," or the idea of } \\
\text { wisdom and exaggerated } \\
\text { intelligence } \\
\text { - difficult to observe and } \\
\text { verify from a first person } \\
\text { perspective }\end{array}$ & $\begin{array}{l}\text { Broom, 2020; } \\
\text { DeGrazia, 1996; } \\
\text { Harris \& Anthis, } \\
\underline{2021}\end{array}$ \\
\hline
\end{tabular}




\begin{tabular}{|c|c|c|c|c|}
\hline & experiences" & & & \\
\hline Smart & 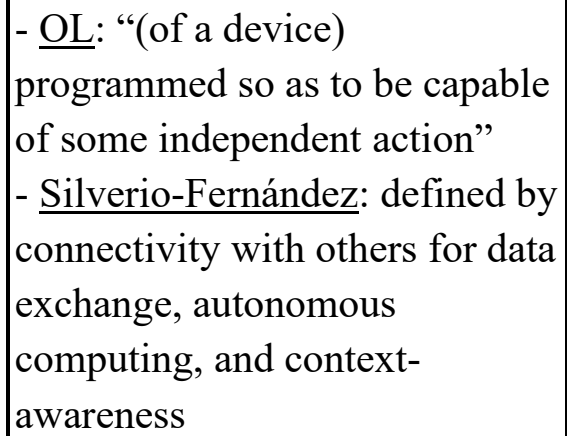 & $\begin{array}{l}\text { - commonly understood to } \\
\text { mean "intelligent" } \\
\text { - can imply autonomy } \\
\text { - sometimes used in relation to } \\
\text { technological systems }\end{array}$ & $\begin{array}{l}\text { - does not necessarily imply } \\
\text { relationality with humans } \\
\text { - often applied to technology } \\
\text { with limited intelligence } \\
\text { (e.g., "smart TV") } \\
\text { - no relationship to moral } \\
\text { consideration }\end{array}$ & $\begin{array}{l}\text { Oxford Languages, } \\
\text { 2021; Silverio- } \\
\text { Fernández et al., } \\
\underline{2018}\end{array}$ \\
\hline
\end{tabular}


Combinations of feature and role terms have been used within and across many fields of study ${ }^{4}$ to describe artificial entities. For instance, "friendly AI" has been used to describe AIs who mimic human friendliness and are benign to humans. "Moral machine" has been used to describe machines that make ethical decisions or need to solve moral dilemmas, like self-driving cars. Some of these combinations are more widely used and well-known. Other combinations have stronger implications for taking moral action and receiving moral consideration. Many combinations are used only in specific contexts, based on convenience, or merely as placeholders. Below we outline some combinations that we think are consequential and related to the moral consideration of artificial entities.

\footnotetext{
${ }^{4}$ See the Appendix for a list of terms defining relevant fields of study.
} 
Table 4: Consequential combinations of features and role

\begin{tabular}{|c|c|c|c|c|}
\hline \multicolumn{5}{|c|}{ Consequential Combinations } \\
\hline Term & Definition(s) & Benefits & Drawbacks & Source(s) \\
\hline Artificial agent & $\begin{array}{l}\text { an interactive, autonomous, } \\
\text { adaptable entity instantiated } \\
\text { at least partly on non- } \\
\text { biological substrates }\end{array}$ & $\begin{array}{l}\text { - grants capacity for taking } \\
\text { independent, self-controlled } \\
\text { actions to at least partly non- } \\
\text { biological entities } \\
\text { - clearly identifies that the } \\
\text { entity is at least partly non- } \\
\text { biological } \\
\text { - addresses relationality } \\
\text { - could be used as a general } \\
\text { term for a class of entities } \\
\text { built (at least initially) by } \\
\text { humans }\end{array}$ & $\begin{array}{l}\text { - may limit moral } \\
\text { consideration because of the } \\
\text { emphasis on agency } \\
\text { - relationality is not clearly } \\
\text { linked to moral } \\
\text { consideration } \\
\text { - may limit humans" } \\
\text { conceptions of the capacities } \\
\text { of these entities } \\
\text { - subject to concerns about } \\
\text { "fakeness" }\end{array}$ & $\begin{array}{l}\text { Floridi \& Sanders, } \\
\underline{2004} \\
\end{array}$ \\
\hline Artificial being & $\begin{array}{l}\text { a distinct and independent } \\
\text { existence instantiated at least } \\
\text { partly on non-biological } \\
\text { substrates }\end{array}$ & $\begin{array}{l}\text { - easily understandable } \\
\text { - familiar } \\
\text { - implies potential for } \\
\text { experiential capacities based } \\
\text { on "life-like" qualities of } \\
\text { "being" } \\
\text { - clearly identifies that the } \\
\text { entity is at least partly non- } \\
\text { biological }\end{array}$ & $\begin{array}{l}\text { - may have different } \\
\text { meanings across contexts } \\
\text { - closely related to legal } \\
\text { concepts like "artificial } \\
\text { person" } \\
\text { - colloquial } \\
\text { - subject to concerns about } \\
\text { "fakeness" } \\
\text { - may imply requirement of } \\
\text { a soul or metaphysical }\end{array}$ & - \\
\hline
\end{tabular}




\begin{tabular}{|c|c|c|c|c|}
\hline & & & presence & \\
\hline $\begin{array}{l}\text { Artificial } \\
\text { consciousness }\end{array}$ & $\begin{array}{l}\text { - Graziano: "a machine that } \\
\text { contains a rich internal model } \\
\text { of what consciousness is, } \\
\text { attributes that property of } \\
\text { consciousness to itself and to } \\
\text { the people it interacts with, } \\
\text { and uses that attribution to } \\
\text { make predictions about } \\
\text { human behavior. Such a } \\
\text { machine would 'believe' it is } \\
\text { conscious and act like it is } \\
\text { conscious, in the same sense } \\
\text { that the human machine } \\
\text { believes and acts" } \\
\text { - Reggia: "computational } \\
\text { models of various aspects of } \\
\text { the conscious mind, either } \\
\text { with software on computers } \\
\text { or in physical robotic } \\
\text { devices" }\end{array}$ & $\begin{array}{l}\text { - implies capacity for } \\
\text { introspection, self-awareness, } \\
\text { and consciousness in a human- } \\
\text { built (at least initially) entity } \\
\text { akin to that present in humans } \\
\text { - emphasizes internal } \\
\text { experiences } \\
\text { - established and already used } \\
\text { in scholarship } \\
\end{array}$ & $\begin{array}{l}\text { - subject to the same } \\
\text { philosophical and empirical } \\
\text { criticisms about } \\
\text { "consciousness" } \\
\text { - unclear what material } \\
\text { components (e.g., body) are } \\
\text { necessary } \\
\text { - complex relationship to } \\
\text { moral consideration } \\
\text { - potential association with } \\
\text { "fake" or "unnatural" } \\
\text { - requires evidence of } \\
\text { consciousness } \\
\text { - may be controversial in use } \\
\text { with the general public } \\
\text { - difficult to observe and } \\
\text { verify from a first person } \\
\text { perspective }\end{array}$ & $\begin{array}{l}\text { Graziano, 2017; } \\
\text { Reggia, 2013 }\end{array}$ \\
\hline Artificial entity & $\begin{array}{l}\text { a distinct and independent } \\
\text { existence instantiated at least } \\
\text { partly on non-biological } \\
\text { substrates }\end{array}$ & $\begin{array}{l}\text { - easily understandable } \\
\text { - familiar } \\
\text { - reflects diversity in possible } \\
\text { types of entities } \\
\text { - clearly identifies that the } \\
\text { entity is at least partly non- } \\
\text { biological }\end{array}$ & $\begin{array}{l}\text { - abstract } \\
\text { - may have different } \\
\text { meanings across contexts } \\
\text { - used commonly to refer to } \\
\text { corporations } \\
\text { - subject to questions about } \\
\text { "fakeness" }\end{array}$ & - \\
\hline
\end{tabular}




\begin{tabular}{|c|c|c|c|c|}
\hline & & $\begin{array}{l}\text { - not tied to existence of a soul } \\
\text { or metaphysical presence }\end{array}$ & - may prompt objectification & \\
\hline $\begin{array}{l}\text { Artificial general } \\
\text { intelligence }\end{array}$ & $\begin{array}{l}\text { "a software program that can } \\
\text { solve a variety of complex } \\
\text { problems in a variety of } \\
\text { different domains, and that } \\
\text { controls itself autonomously, } \\
\text { with its own thoughts, } \\
\text { worries, feelings, strengths, } \\
\text { weaknesses and } \\
\text { predispositions" }\end{array}$ & $\begin{array}{l}\text { - established and commonly } \\
\text { used } \\
\text { - may prompt increased } \\
\text { similarity to humanity and } \\
\text { thus make it easier to promote } \\
\text { moral consideration } \\
\text { - emphasizes internal } \\
\text { phenomena (e.g., software } \\
\text { programming, mental } \\
\text { capacities) rather than external } \\
\text { properties (e.g., material } \\
\text { structure, embodiment) }\end{array}$ & $\begin{array}{l}\text { - implicit connection with } \\
\text { human-like or a human-like } \\
\text { basis for intelligence } \\
\text { requires humans to be the } \\
\text { initial standard } \\
\text { - potential association with } \\
\text { "fake" or "unnatural" } \\
\text { - limited by existing } \\
\text { conceptual bounds of AIs as } \\
\text { cognitively skilled machines } \\
\text { - definition susceptible to } \\
\text { meaning changes over time } \\
\text { as technology and } \\
\text { conceptions of "intelligence" } \\
\text { change } \\
\text { - may require evidence of } \\
\text { self-awareness or } \\
\text { consciousness }\end{array}$ & $\frac{\text { Goertzel \& }}{\text { Pennachin, } 2007}$ \\
\hline $\begin{array}{l}\text { Artificial } \\
\text { intelligence }\end{array}$ & $\begin{array}{l}\text { "systems that can decide } \\
\text { what to do and do it" and that } \\
\text { vary based on how human- } \\
\text { like and/or rational their } \\
\text { thought processes and/or } \\
\text { behavior are }\end{array}$ & $\begin{array}{l}\text { - well-known and commonly } \\
\text { used } \\
\text { - entails specific capacities } \\
\text { (e.g., memory, learning, } \\
\text { reasoning) }\end{array}$ & $\begin{array}{l}\text { - used interchangeably to } \\
\text { signify the field of study, an } \\
\text { individual entity, or a } \\
\text { network of entities } \\
\text { - potential association with } \\
\text { "fake" or "unnatural" } \\
\text { - established usage is } \\
\text { conflated with sophisticated }\end{array}$ & Russell \& Norvig, \\
\hline
\end{tabular}




\begin{tabular}{|c|c|c|c|c|}
\hline & & & $\begin{array}{l}\text { cognition } \\
\text { - depends on conceptions of } \\
\text { human-like intelligence } \\
\text { - definition susceptible to } \\
\text { meaning changes over time } \\
\text { as technology and } \\
\text { conceptions of "intelligence" } \\
\text { change } \\
\text { - not typically connected } \\
\text { with moral consideration } \\
\text { - may be prone to hype }\end{array}$ & \\
\hline $\begin{array}{l}\text { Artificial moral } \\
\text { agent }\end{array}$ & 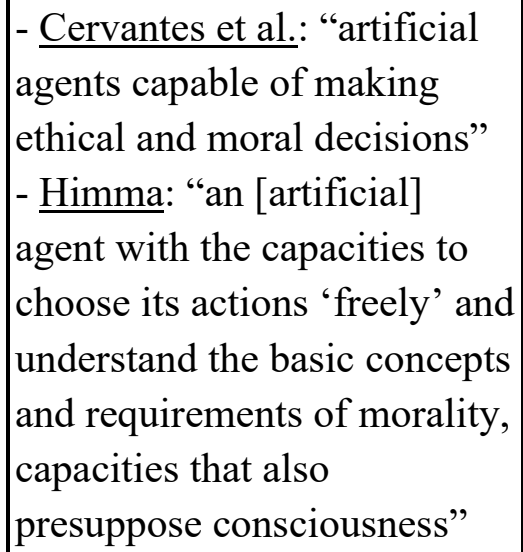 & $\begin{array}{l}\text { - promotes association of } \\
\text { artificial entities with morality } \\
\text { - clearly signifies an } \\
\text { individual } \\
\text { - entails specific types of } \\
\text { decisions and actions } \\
\text { - considers internal } \\
\text { experiences of artificial } \\
\text { entities }\end{array}$ & $\begin{array}{l}\text { - may be associated only } \\
\text { with taking moral action } \\
\text { rather than with receiving } \\
\text { moral consideration } \\
\text { - may require evidence of } \\
\text { consciousness } \\
\text { - context specific moral } \\
\text { boundaries may introduce } \\
\text { safety concerns or present a } \\
\text { threat to humans }\end{array}$ & $\begin{array}{l}\text { Cervantes et al., } \\
\text { 2020; Himma, } 2009 \\
\end{array}$ \\
\hline Artificial sentience & $\begin{array}{l}\text { - artificial entities with the } \\
\text { capacity for positive and } \\
\text { negative experiences, such as } \\
\text { happiness and suffering } \\
\text { - the capacity for positive and } \\
\text { negative experiences } \\
\text { manifested in artificial }\end{array}$ & $\begin{array}{l}\text { - clear connection to moral } \\
\text { consideration from the } \\
\text { nonhuman animal research on } \\
\text { sentience } \\
\text { - represents specific, valenced } \\
\text { experiential capacities } \\
\text { - does not require human-like }\end{array}$ & $\begin{array}{l}\text { - could signify an individual } \\
\text { entity, a collection of } \\
\text { entities, a } \\
\text { psychological/phenomenal } \\
\text { experience, or a field of } \\
\text { study } \\
\text { - little established scholarly }\end{array}$ & $\begin{array}{l}\text { Sentience Institute, } \\
2021\end{array}$ \\
\hline
\end{tabular}




\begin{tabular}{|c|c|c|c|c|}
\hline & entities & $\begin{array}{l}\text { intelligence } \\
\text { - dissociable from cognitive } \\
\text { capacities like problem- } \\
\text { solving and analytical thinking } \\
\text { - may be more distinctive than } \\
\text { "mind" or "consciousness" } \\
\text { - prioritizes perception, } \\
\text { emotion, and behavior }\end{array}$ & $\begin{array}{l}\text { or applied usage } \\
\text { - potential association with } \\
\text { "fake" or "unnatural" } \\
\text { - potential conflation with } \\
\text { "artificial consciousness" } \\
\text { due to historical } \\
\text { philosophical link between } \\
\text { "sentience" and } \\
\text { "consciousness" } \\
\text { - difficult to observe and } \\
\text { verify from a first person } \\
\text { perspective }\end{array}$ & \\
\hline Digital mind & $\begin{array}{l}\text { - } \underline{S \& B} \text { : "machine minds with } \\
\text { conscious experiences, } \\
\text { desires, and capacity for } \\
\text { reasoning and autonomous } \\
\text { decision-making" } \\
\text { - Sotala: "a mind that runs on } \\
\text { a computer" }\end{array}$ & $\begin{array}{l}\text { - bridges interdisciplinary } \\
\text { conceptions of "mind" (e.g., } \\
\text { psychology, artificial } \\
\text { intelligence) } \\
\text { - inclusive of a range of } \\
\text { machine-based entities (e.g., } \\
\text { whole brain emulations, AI } \\
\text { algorithms) } \\
\text { - existing theorizing on moral } \\
\text { status and the potential to } \\
\text { experience suffering } \\
\text { - highlights non-material } \\
\text { aspects of entities }\end{array}$ & $\begin{array}{l}\text { - some research uses this } \\
\text { term to refer to human } \\
\text { brains interacting with } \\
\text { digital media } \\
\text { - tied to instrumental use } \\
\text { purposes (e.g., "digital mind } \\
\text { mapping," "digital mind } \\
\text { games") } \\
\text { - implied connection with } \\
\text { the human brain or systems } \\
\text { initially modelled on } \\
\text { biological brains }\end{array}$ & $\frac{\text { Shulman \& Bostrom, }}{2021 ; \text { Sotala, } 2012}$ \\
\hline Digital person & $\begin{array}{l}\text { - EA: "a person running on } \\
\text { digital computing hardware" } \\
\text { - Karnofsky: digital copies of }\end{array}$ & $\begin{array}{l}\text { - connection to "humanness" } \\
\text { and human capacities like } \\
\text { sentience that may increase }\end{array}$ & $\begin{array}{l}\text { - implied connection with } \\
\text { the human brain or systems } \\
\text { initially modelled on }\end{array}$ & $\begin{array}{l}\text { Effective Altruism } \\
\text { Forum, 2021; } \\
\text { Karnofsky, 2021 } \\
\end{array}$ \\
\hline
\end{tabular}




\begin{tabular}{|c|c|c|c|c|}
\hline & $\begin{array}{l}\text { humans such as simulated } \\
\text { human brains and digital } \\
\text { descendants of humanity }\end{array}$ & $\begin{array}{l}\text { moral consideration } \\
\text { - framework may make the } \\
\text { concept more accessible to the } \\
\text { general public } \\
\text { - highlights non-material } \\
\text { aspects of entities }\end{array}$ & $\begin{array}{l}\text { biological brains } \\
\text { - excludes many types of } \\
\text { artificial entities, notably } \\
\text { those who are less human- } \\
\text { like or not descended from } \\
\text { humans } \\
\text { - the future framing of the } \\
\text { concept may reduce its near- } \\
\text { and medium-term impact }\end{array}$ & \\
\hline Full ethical agent & $\begin{array}{l}\text { "can make explicit ethical } \\
\text { judgments and generally is } \\
\text { competent to reasonably } \\
\text { justify them" }\end{array}$ & $\begin{array}{l}\text { - implies specific and } \\
\text { directional action tied to } \\
\text { morality } \\
\text { - can be used in connection } \\
\text { with making moral judgments } \\
\text { - implies greater depth of } \\
\text { agency with the term "full" } \\
\text { - can apply to any entity with } \\
\text { the capacity to make ethical } \\
\text { judgments, human or } \\
\text { nonhuman }\end{array}$ & $\begin{array}{l}\text { - does not uniquely } \\
\text { distinguish artificial entities } \\
\text { and their capacities } \\
\text { - does not consider the } \\
\text { perceptual, affective, and } \\
\text { experiential capacities of the } \\
\text { entity } \\
\text { - not commonly used } \\
\text { - may promote a false binary } \\
\text { distinction between moral } \\
\text { agency and moral patiency }\end{array}$ & Moor, 2006 \\
\hline Intelligent systems & $\begin{array}{l}\text { "a tool that (1) operates in a } \\
\text { complex world with limited } \\
\text { resources (2) possesses } \\
\text { primary cognitive abilities } \\
\text { such as perception, action } \\
\text { control, reasoning, or } \\
\text { language use, and (3) exhibits } \\
\text { complex intelligent behavior }\end{array}$ & $\begin{array}{l}\text { - commonly used and } \\
\text { understood to signify AI } \\
\text { - implies multiple cooperating } \\
\text { components that may be } \\
\text { important for moral } \\
\text { consideration } \\
\text { - entails a detailed breakdown } \\
\text { of capacities }\end{array}$ & $\begin{array}{l}\text { - applicable primarily to } \\
\text { describing cognitive } \\
\text { capacities; little } \\
\text { consideration of perceptual, } \\
\text { affective, or experiential } \\
\text { capacities } \\
\text { - depends on conceptions of } \\
\text { human-like intelligence }\end{array}$ & Molina, 2020 \\
\hline
\end{tabular}




\begin{tabular}{|c|c|c|c|c|}
\hline & $\begin{array}{l}\text { supported by abilities such as } \\
\text { rationality, adaptation } \\
\text { through learning, or the } \\
\text { ability to explain the use of } \\
\text { its knowledge by } \\
\text { introspection", }\end{array}$ & - implies internal complexity & $\begin{array}{l}\text { - strong associations with } \\
\text { instrumental purposes (i.e., } \\
\text { as tools) } \\
\text { - little connection with moral } \\
\text { consideration }\end{array}$ & \\
\hline $\begin{array}{l}\text { Machine } \\
\text { superintelligence }\end{array}$ & $\begin{array}{l}\text { "general artificial intelligence } \\
\text { greatly outstripping the } \\
\text { cognitive capacities of } \\
\text { humans, and capable of } \\
\text { bringing about revolutionary } \\
\text { technological and economic } \\
\text { advances" }\end{array}$ & $\begin{array}{l}\text { - "machine" implies some sort } \\
\text { of material structure } \\
\text { - points to societal } \\
\text { ramifications of AI } \\
\text { - points to a minimum of } \\
\text { general intelligence rather than } \\
\text { intelligence only in specific } \\
\text { tasks, processes, or certain } \\
\text { domains }\end{array}$ & $\begin{array}{l}\text { - could be criticized for not } \\
\text { incorporating considerations } \\
\text { of reinforcement learning AI } \\
\text { (e.g., like in this podcast) } \\
\text { - uses human intelligence as } \\
\text { the standard of comparison } \\
\text { - experiential, affective } \\
\text { capacities typically not } \\
\text { discussed which may limit } \\
\text { moral consideration } \\
\text { - could threaten human } \\
\text { uniqueness and resources } \\
\text { - implies a linear and } \\
\text { hierarchical progression of } \\
\text { capacities rather than a } \\
\text { possible equivalency of } \\
\text { capacities }\end{array}$ & Bostrom et al., 2020 \\
\hline Moral agent & $\begin{array}{l}\text { an entity who can take moral } \\
\text { action }\end{array}$ & $\begin{array}{l}\text { - specific and directional } \\
\text { action tied to morality } \\
\text { - can be used in reference to } \\
\text { taking moral action } \\
\text { - widely used across multiple }\end{array}$ & $\begin{array}{l}\text { - does not uniquely } \\
\text { distinguish artificial entities } \\
\text { and their capacities } \\
\text { - may imply less worthiness } \\
\text { of moral consideration }\end{array}$ & Floridi \& Sanders, \\
\hline
\end{tabular}




\begin{tabular}{|c|c|c|c|c|}
\hline & & $\begin{array}{l}\text { disciplines (e.g., psychology, } \\
\text { philosophy, AI, HRI, HCI) } \\
\text { - can apply to any entity with } \\
\text { the capacity to take moral } \\
\text { actions, human or nonhuman }\end{array}$ & & \\
\hline Moral patient & $\begin{array}{l}\text { an entity who can receive } \\
\text { moral action }\end{array}$ & $\begin{array}{l}\text { - specific and directional } \\
\text { action tied to morality } \\
\text { - can be used in reference to } \\
\text { granting moral consideration } \\
\text { - widely used across multiple } \\
\text { disciplines (e.g., psychology, } \\
\text { philosophy, AI, HRI, HCI) } \\
\text { - can apply to any entity with } \\
\text { the capacity to receive moral } \\
\text { actions, human or nonhuman }\end{array}$ & $\begin{array}{l}\text { - does not uniquely } \\
\text { distinguish artificial entities } \\
\text { and their capacities } \\
\text { - may imply less potential } \\
\text { for moral agency }\end{array}$ & Floridi \& Sanders, \\
\hline $\begin{array}{l}\text { Non-biological } \\
\text { sentience }\end{array}$ & $\begin{array}{l}\text { - non-carbon-based entities } \\
\text { without biological qualities } \\
\text { who have the capacity for } \\
\text { positive and negative } \\
\text { experiences, such as } \\
\text { happiness and suffering } \\
\text { - the capacity for positive and } \\
\text { negative experiences } \\
\text { manifested in non-biological } \\
\text { entities }\end{array}$ & $\begin{array}{l}\text { - clear connection with moral } \\
\text { consideration from the } \\
\text { nonhuman animal research on } \\
\text { sentience } \\
\text { - represents specific, valenced } \\
\text { experiential capacities } \\
\text { - does not require human-like } \\
\text { intelligence } \\
\text { - dissociable from cognitive } \\
\text { capacities like problem- } \\
\text { solving and analytical thinking } \\
\text { - may be more distinctive than } \\
\text { "mind" or "consciousness" }\end{array}$ & $\begin{array}{l}\text { - could signify an individual } \\
\text { entity, a collection of } \\
\text { entities, a } \\
\text { psychological/phenomenal } \\
\text { experience, or a field of } \\
\text { study } \\
\text { - little established scholarly } \\
\text { or applied usage } \\
\text { - difficult to observe and } \\
\text { verify from a first person } \\
\text { perspective } \\
\text { - may increase the focus on } \\
\text { material feature or substrate }\end{array}$ & - \\
\hline
\end{tabular}




\begin{tabular}{|c|c|c|c|c|}
\hline & & $\begin{array}{l}\text { - prioritizes perception, } \\
\text { emotion, and behavior } \\
\text { - may avoid issues of } \\
\text { "fakeness" or "unnaturalness" } \\
\text { - not subject to the hype } \\
\text { associated with AI } \\
\text { - less subject to the value } \\
\text { judgment of "living" }\end{array}$ & $\begin{array}{l}\text { rather than psychological or } \\
\text { perceptual features that } \\
\text { increase moral consideration } \\
\text { - may be problematic in } \\
\text { future scenarios with non- } \\
\text { carbon-based biological } \\
\text { lifeforms } \\
\text { - difficult to apply to } \\
\text { artificial entities arising } \\
\text { from evolutionarily } \\
\text { biological processes (e.g., } \\
\text { whole brain emulations) } \\
\text { - may exclude hybrid } \\
\text { biological and non- } \\
\text { biological systems } \\
\text { - potentially meaningless in } \\
\text { systems or worlds without } \\
\text { any "biological" components }\end{array}$ & \\
\hline Smart device & $\begin{array}{l}\text { "context-aware electronic } \\
\text { device capable of performing } \\
\text { autonomous computing and } \\
\text { connecting to other devices } \\
\text { wire or wirelessly for data } \\
\text { exchange" }\end{array}$ & $\begin{array}{l}\text { - decent shorthand to } \\
\text { distinguish devices with some } \\
\text { level of intelligent response } \\
\text { from entirely non-intelligent } \\
\text { mechanical or electronic } \\
\text { devices } \\
\text { - emphasizes autonomy } \\
\text { - emphasizes relationality with } \\
\text { other artificial entities }\end{array}$ & $\begin{array}{l}\text { - used primarily in } \\
\text { instrumental contexts (e.g., } \\
\text { technological tools) } \\
\text { - diversity of included } \\
\text { entities with varying levels } \\
\text { of intelligent capacities may } \\
\text { weaken arguments for moral } \\
\text { consideration (e.g., personal } \\
\text { assistance device, smart TV, } \\
\text { smart phone) }\end{array}$ & Silverio-Fernández et \\
\hline
\end{tabular}




\begin{tabular}{|c|c|c|c|c|}
\hline & & & $\begin{array}{l}\text { - used largely in human } \\
\text { consumer contexts }\end{array}$ & \\
\hline Super-beneficiary & $\begin{array}{l}\text { "a being that is superhumanly } \\
\text { efficient at deriving well- } \\
\text { being from resources" }\end{array}$ & $\begin{array}{l}\text { - clearly implies a need for } \\
\text { moral consideration } \\
\text { - prioritizes well-being } \\
\text { - extends conceptions of } \\
\text { beneficiaries to artificial } \\
\text { entities }\end{array}$ & $\begin{array}{l}\text { - potentially threatening to } \\
\text { the needs and resource } \\
\text { allocation of humans and } \\
\text { nonhuman animals } \\
\text { - "utility monster" } \\
\text { - may be susceptible to the } \\
\text { stereotype of welfare } \\
\text { recipients who make use of } \\
\text { the system for personal gain } \\
\text { rather than because of need } \\
\text { - may lead to negative } \\
\text { consequences like increased } \\
\text { prejudice and moral } \\
\text { exclusion } \\
\text { - implies a linear and } \\
\text { hierarchical progression of } \\
\text { capacities rather than a } \\
\text { possible equivalency of } \\
\text { capacities }\end{array}$ & Shulman \& Bostrom, \\
\hline Super-patient & $\begin{array}{l}\text { "a being with superhuman } \\
\text { moral status" }\end{array}$ & $\begin{array}{l}\text { - implies a need for moral } \\
\text { consideration } \\
\text { - extends moral patiency to } \\
\text { intelligent artificial entities }\end{array}$ & $\begin{array}{l}\text { - potentially threatening to } \\
\text { the needs and resources of } \\
\text { humans and nonhuman } \\
\text { animals } \\
\text { - may lead to negative } \\
\text { consequences like increased } \\
\text { prejudice and moral }\end{array}$ & Shulman \& Bostrom, \\
\hline
\end{tabular}




\begin{tabular}{|c|c|c|c|c|}
\hline & & & $\begin{array}{l}\text { exclusion } \\
\text { - implies a linear and } \\
\text { hierarchical progression of } \\
\text { capacities rather than a } \\
\text { possible equivalency of } \\
\text { capacities }\end{array}$ & \\
\hline $\begin{array}{l}\text { Transformative } \\
\text { artificial } \\
\text { intelligence }\end{array}$ & $\begin{array}{l}\text { "AI that precipitates a } \\
\text { transition comparable to (or } \\
\text { more significant than) the } \\
\text { agricultural or industrial } \\
\text { revolution" }\end{array}$ & $\begin{array}{l}\text { - intended to include many } \\
\text { possible artificial entities } \\
\text { - intended to be agnostic to } \\
\text { human-likeness } \\
\text { - implies an advance in the } \\
\text { capacities of artificial entities } \\
\text { that may enable increased } \\
\text { moral consideration }\end{array}$ & $\begin{array}{l}\text { - might be limited to } \\
\text { artificial entities in only } \\
\text { some contexts (e.g., AIs } \\
\text { working in data science) } \\
\text { - may threaten human } \\
\text { resources or uniqueness } \\
\text { - depends somewhat on } \\
\text { conceptions of human-like } \\
\text { intelligence } \\
\text { - experiential, affective } \\
\text { capacities not integral to the } \\
\text { concept } \\
\text { - framed around } \\
\text { transformation of current } \\
\text { human society rather than } \\
\text { transformation of artificial } \\
\text { entities }\end{array}$ & Karnofsky, 2016 \\
\hline
\end{tabular}




\section{What term should we use?}

Is the same terminology useful for the general public, engineers, scientists, ethicists, lawyers, and policy-makers? There's some suggestion that the general public and experts differ in their understanding of artificial entities and support for their rights. Would a common, consensual terminology enable more effective interdisciplinary research, policy-making, and advocacy? If having an imprecise definition is preferred, how can differences in terminology be reconciled to maximize the clarity and utility of the terms?

Whether or not terms generalize across contexts might matter. Should we use terminology that can be applied to humans, nonhuman animals, algorithms, and machines? Is it necessary to specify an entity's role? Several of the consequential combinations do not (e.g., "artificial general intelligence," "artificial sentience"). Does the psychological feature need to be narrow or broad? "Consciousness" is broad, but it is also "fuzzy" because of the many conceptualizations in current usage. On the other hand, a narrow term like "friendly" only applies to one aspect of an entity's behavior and may not retain meaning over time and across context.

Below we explain our preference for "artificial sentience," consider some possible reasons not to use "artificial sentience," and consider using multiple terms.

\section{Reasons for "artificial sentience"}

We favor the term "artificial sentience" for the following linguistic reasons:

- "Artificial sentience" sits in a "Goldilocks Zone" of broad and narrow terminology. "Artificial" is inclusive of many entities and distinguishes entities composed at least partly of non-biological substrates from completely biological entities. "Artificial" is commonly used and understood in relevant contexts. "Sentience" is an aspect of "mind" that can be differentiated from broad and narrow psychological features such as "mind" and "intelligence," respectively.

- "Artificial sentience," as a newer term, does not have divergent meanings across time and field of study like the dual meanings that exist for some terms (e.g., "digital mind"). Scholars concerned with the effects of AIs on human society have used "digital mind" to refer to psychological minds that exist purely on a computer or in a digital space. The term is also associated with human brains and the dynamics of digital technologies. In this context, a "digital mind" is a human brain on digital media.

- "Artificial sentience" uses similar language to "artificial intelligence" and is likely to be conceptually associated with it. "Artificial intelligence" has a well-established meaning and is commonly used by the general public and experts. We believe that similarity to the well-known "artificial intelligence" will enable experts and the public alike to grasp the meaning of "artificial sentience" as an "experiential" extension of "artificial intelligence."

- There is little reason to expect the term "artificial sentience" to be associated with Godlike terms such as "machine superintelligence" that reduce moral consideration by dint of being too threatening or tool-like terms such as "smart device" that prompt instrumental mental images. The common conception of artificial entities as technological tools may limit the extent to which they are morally considered and overcoming these associations 
with existing terminology may be difficult.

We favor the term "artificial sentience" for the following conceptual reasons:

- "Artificial sentience" avoids some of the conceptual difficulties associated with "artificial consciousness." Some stances within philosophy, including a position held at SI, argue that the construct of "consciousness" and some of its underlying mental circuitry (e.g., how introspection arises from neural and cognitive systems) are particularly ill-defined and difficult to observe.

- "Artificial sentience" is inclusive of entirely non-biological entities, hybrid biological and non-biological entities, and artificial entities originating from evolutionarily biological processes like whole brain emulations. This inclusivity may increase the tractability of advocating for the moral consideration of artificial entities in a way that terms like "nonbiological sentience" may not.

- The term "artificial sentience" prioritizes "sentience," an affective capacity, as the key distinguishing aspect of mind critical to experiential capacities like motivation and affect. Although "mind" encompasses all mental capacities, it is sometimes used to signify only cognition, reasoning, and rationality. This usage of "mind" is often implicitly considered "cold," controlled, and unemotional, which can lead to mechanistic forms of dehumanization and moral circle exclusion.

- "Sentience" requires features related to having affective experiences (e.g., the capacity to have positive and negative experiences). This definition may make "sentience" less subject to "fuzziness" than other psychological features that are difficult to define and observe like "qualia."

- "Artificial sentience" may be less threatening to people than terms like "superbeneficiary," "digital mind," or "artificial consciousness." "Super-beneficiary" may prompt realistic threats over resource sharing. "Digital mind" and "artificial consciousness" may prompt symbolic threats to human distinctiveness because of the association of "consciousness" and "mind" with humans' sophisticated mental capacities. "Artificial sentience" may be less threatening because "sentience" is not unique to humans and because "sentience" does not necessarily imply sharing resources or social status.

We favor the term "artificial sentience" for the following moral reasons:

- "Artificial sentience" connotes the aspect of artificial entities' minds that we believe is critical to moral consideration. Affective components of mind like sentience are linked to increased moral consideration. Cognitive components of mind like memory are typically associated with the capacity to take moral action. ${ }^{5}$ We believe that this may be an important distinction for moral consideration given the potential need to distinguish between future "digital minds" who have some degree of sentience and "digital minds" that are cognitively sophisticated but devoid of experiential capacities.

- "Sentience" is the psychological feature most clearly related to the moral consideration of nonhumans. Specifically, "sentience" has a clear track record in nonhuman animal welfare science and advocacy for moral consideration and has some backing within AI ethics.

${ }^{5}$ Summarizing from Gray et al. (2007) and Gray et al. (2012). 
"Consciousness" has a more convoluted relationship with moral consideration.

- There are clear consequences of sentience dismissal for humans (e.g., the Atlantic slave trade) and nonhumans (e.g., factory farming). The capacity to suffer is denied with sentience dismissal, facilitating exclusion from the moral circle. "Artificial sentience" is likely to be critical for recognizing the moral status of sentient artificial entities in a way that consequential combinations like "artificial consciousness" are not.

\section{Reasons against "artificial sentience"}

- The use of "artificial" may lead to some associations with "fakeness" or "unnaturalness." This could be a concern if it leads to the dismissal of artificial entities' capacity to have socalled "real" experiences.

- "Artificial sentience" may be more threatening than terms like "non-biological sentience"6 if people associate "artificial" with being constructed in a laboratory for nefarious purposes or if they associate "artificial intelligence" with dangers outside of human control.

- The use of "sentience" is sometimes conflated with "sapience," or conceptions of exaggerated intelligence, wisdom, and reasoning. This could be a concern for promoting understandings of what artificial sentience entails.

- "Artificial sentience" is new and unfamiliar to the general public and many experts. This could lead to some initial confusion. The longevity of the term could also be questioned. Given that it is new, we cannot yet know whether or not it will endure meaningfully into the future.

- "Artificial sentience" has some philosophical overlap with "artificial consciousness" that may increase confusion over the meaning of the term when used in interdisciplinary or transdisciplinary contexts. This overlap may also mean that some critiques of "artificial consciousness" may apply to conceptions of "artificial sentience" that are too broadly defined (e.g., broader than the capacity for positive and negative experiences).

- The connection between "artificial intelligence" and "artificial sentience" might create a spillover of hype from AI. Ungrounded excitement could prompt increased efforts to develop artificial sentience without enough forethought and preparation for a world with sentient artificial entities who may or may not receive moral consideration.

- "Artificial sentience" is likely to require evidence of the presence of a number of relevant features (e.g., those related to detecting harmful stimuli, behavioral avoidance, centralized information processing) that may enable us to make judgments about the likelihood and degree of sentience. This could enable a probabilistic approach for operationalizing "artificial sentience" that might increase our chances of correctly judging whether an artificial entity is sentient (advancing the moral consideration of artificial entities). However, having to calculate the probability of artificial sentience may make it easier for some to dismiss the existence of "artificial sentience" given that it may reduce confidence in the concept by providing too much evidence.

\footnotetext{
${ }^{6}$ A term like "non-biological sentience" might contrast better with "biological sentience," increasing the focus on "sentience" rather than on the entity's material features and substrate (i.e., whether they are a human, a nonhuman animal, algorithm, or machine). Reducing the emphasis on substrate may facilitate attempts to increase the moral consideration of artificial entities.
} 


\section{Using multiple terms}

The best strategy might be to use multiple terms to represent the interests of algorithmically-based, at least partly non-biological entities, of which artificial sentience (AS) may eventually be considered an umbrella term. Below is a possible initial taxonomy of terms based on their relationship to the moral referents of patiency and agency and to the specificity of the term.

Figure: Possible Taxonomy of Terms

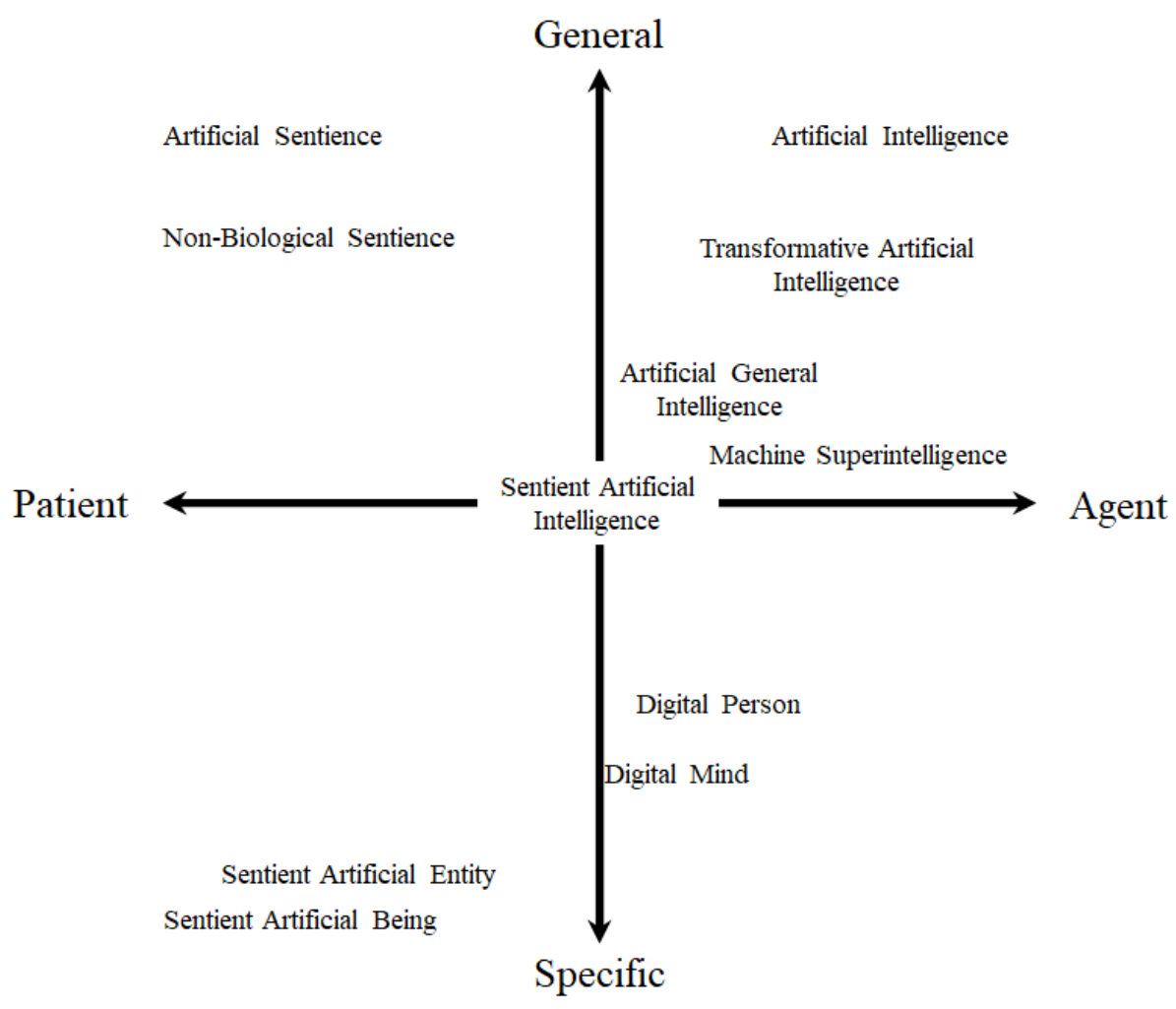

Note. Terms are positioned along two (of many possible) dimensions. Moral references are on the $x$-axis and specificity is along the $y$-axis. These locations are imprecise as they reflect cultural and intellectual associations that are likely to vary across readers and change over time.

Possible Uses for Specific Terms

- "Sentient artificial being" and "sentient artificial entity" are likely to be useful for communicating about individual AIs with non-experts or in discussions where the emphasis is on sentience rather than intelligence.

- "Sentient artificial intelligence" ("sentient AI") is likely to be useful for communicating with experts and non-experts about individual AIs with some degree of sentience or the capacity for sentience in AI.

- "Digital mind" is likely to be useful for emphasizing internal, algorithmic mental capacities rather than substrate-based material structures. 
- "Digital people"7 is likely to be useful when referring to the digital nature of human descendants and the sorts of societies they may live in.

\footnotetext{
${ }^{7}$ See Holden Karnofsky's Cold Takes blog for more on "digital people."
} 


\section{Appendix: Terminology defining relevant fields of study}

Some terms define the academic fields of study surrounding artificial entities. The fields described below seem likely to have the greatest impact on long-term outcomes of artificial entity development such as how they will be designed and the resulting ethical implications.

\begin{tabular}{|c|c|c|c|c|}
\hline \multicolumn{5}{|l|}{ Field of Study } \\
\hline Term & Definition(s) & Benefits & Drawbacks & Source(s) \\
\hline $\begin{array}{l}\text { Computer } \\
\text { ethics }\end{array}$ & $\begin{array}{l}\text { - Maner: "ethical problems } \\
\text { aggravated, transformed or created } \\
\text { by computer technology" } \\
\text { - Moor: contemplating the social } \\
\text { and ethical use of information } \\
\text { technology in order to inform policy } \\
\text { - Bynum: "identifies and analyzes } \\
\text { the impacts of information } \\
\text { technology on such social and } \\
\text { human values as health, wealth, } \\
\text { work, opportunity, freedom, } \\
\text { democracy, knowledge, privacy, } \\
\text { security, self-fulfillment, etc." }\end{array}$ & $\begin{array}{l}\text { - can be applied to protect } \\
\text { humanity from extinction } \\
\text { risks } \\
\text { - can be applied to policies } \\
\text { aimed at the social } \\
\text { integration of artificial } \\
\text { entities }\end{array}$ & $\begin{array}{l}\text { - focused on impacts to } \\
\text { human society } \\
\text { - less relevant to the moral } \\
\text { consideration of nonhumans } \\
\text { - has a diversity of meanings } \\
\text { with some emphasizing } \\
\text { policy and others } \\
\text { emphasizing ethics }\end{array}$ & Bynum, 2004 \\
\hline Machine ethics & $\begin{array}{l}\text { "...concerned with ensuring that the } \\
\text { behavior of machines toward human } \\
\text { users, and perhaps other machines } \\
\text { as well, is ethically acceptable" }\end{array}$ & $\begin{array}{l}\text { - centers machine behavior } \\
\text { instead of human behavior } \\
\text { - allows for the moral } \\
\text { consideration of machines } \\
\text { - can be applied to protect } \\
\text { humanity from extinction } \\
\text { risks }\end{array}$ & $\begin{array}{l}\text { - the moral consideration of } \\
\text { humans is the primary } \\
\text { outcome of concern } \\
\text { - only machines', not } \\
\text { humans', moral } \\
\text { consideration of other } \\
\text { machines is considered }\end{array}$ & $\begin{array}{l}\text { Anderson \& } \\
\text { Anderson, 2007; } \\
\text { Stanford } \\
\text { Encyclopedia of } \\
\text { Philosophy, 2020 } \\
\end{array}$ \\
\hline
\end{tabular}




\begin{tabular}{|c|c|c|c|c|}
\hline & & & $\begin{array}{l}\text { - less emphasis placed on } \\
\text { institutional behavior and } \\
\text { more emphasis on individual } \\
\text { behavior }\end{array}$ & \\
\hline $\begin{array}{l}\text { Robot ethics } \\
\text { ("roboethics") }\end{array}$ & $\begin{array}{l}\text { focused on the ethical and social } \\
\text { implications and consequences of } \\
\text { advanced robotics particularly in } \\
\text { regards to safety and errors, law and } \\
\text { ethics, and social impact }\end{array}$ & $\begin{array}{l}\text { - includes human and robot } \\
\text { perspectives } \\
\text { - can be applied to protect } \\
\text { humanity from extinction } \\
\text { risks }\end{array}$ & $\begin{array}{l}\text { - applicable to robots only } \\
\text { (material body required that } \\
\text { can sense and act on the } \\
\text { world) } \\
\text { - the moral consideration of } \\
\text { humans is more central than } \\
\text { the moral consideration of } \\
\text { robots }\end{array}$ & $\begin{array}{l}\frac{\text { Gunkel, 2018; Lin et }}{\text { al., 2011; Lin et al., }} \\
\underline{2011 ; \text { Scheutz, 2013 }} \\
\end{array}$ \\
\hline $\begin{array}{l}\text { Artificial } \\
\text { intelligence }\end{array}$ & $\begin{array}{l}\text { to understand and build intelligent } \\
\text { entities }\end{array}$ & $\begin{array}{l}\text { - well-known } \\
\text { - encompasses many } \\
\text { exemplars of artificial } \\
\text { entities; broadly inclusive } \\
\text { - encourages } \\
\text { interdisciplinary } \\
\text { contributions and } \\
\text { collaborations }\end{array}$ & $\begin{array}{l}\text { - also used to refer to } \\
\text { individual entities } \\
\text { - focused on cognitive } \\
\text { capacities specifically } \\
\text { around human-like } \\
\text { intelligence defined by } \\
\text { problem-solving and } \\
\text { analytical thinking } \\
\text { - has different meanings for } \\
\text { experts and the general } \\
\text { public } \\
\text { - prone to hype }\end{array}$ & Russell \& Norvig, \\
\hline Cybernetics & $\begin{array}{l}\text { the study of feedback, human } \\
\text { behavior, and information to } \\
\text { understand communication and } \\
\text { control in human-machine }\end{array}$ & $\begin{array}{l}\text { - defined by the } \\
\text { relationality of humans and } \\
\text { machines } \\
\text { - specialized focus on }\end{array}$ & $\begin{array}{l}\text { - implies material integration } \\
\text { of humans (biological) and } \\
\text { machines (non-biological) } \\
\text { - machines not judged as }\end{array}$ & $\frac{\text { Mindell, 2004; }}{\underline{\text { Wiener, } 1948}}$ \\
\hline
\end{tabular}




\begin{tabular}{|c|c|c|c|c|}
\hline & relationships & $\begin{array}{l}\text { dynamic, feedback-based } \\
\text { systems } \\
\text { - safety emphasis on } \\
\text { producing specific outputs } \\
\text { from specific inputs }\end{array}$ & $\begin{array}{l}\text { equivalent in value to } \\
\text { humans } \\
\text { - less commonly used than } \\
\text { other field names }\end{array}$ & \\
\hline $\begin{array}{l}\text { Human - } \\
\text { computer } \\
\text { interaction }\end{array}$ & $\begin{array}{l}\text { ".... a subfield within computer } \\
\text { science concerned with the study of } \\
\text { the interaction between people } \\
\text { (users) and computers and the } \\
\text { design, evaluation and } \\
\text { implementation of user interfaces } \\
\text { for computer systems that are } \\
\text { receptive to the user's needs and } \\
\text { habits. It is a multidisciplinary field, } \\
\text { which incorporates computer } \\
\text { science, behavioral sciences, and } \\
\text { design. A central objective of HCI } \\
\text { is to make computer systems more } \\
\text { user-friendly and more usable." }\end{array}$ & $\begin{array}{l}\text { - focuses on the } \\
\text { relationality of humans and } \\
\text { computers } \\
\text { - incorporates research } \\
\text { from multiple perspectives } \\
\text { and disciplines } \\
\text { - does not require a robotic } \\
\text { body that can sense and act } \\
\text { on the world } \\
\text { - may be more inclusive of } \\
\text { various types of AIs (e.g., } \\
\text { algorithms, robots) }\end{array}$ & \begin{tabular}{|l|} 
- focuses on machines as \\
instrumental tools \\
- benefits of relationality are \\
one-sided (i.e., for humans) \\
- less emphasis on ethics or \\
moral consideration \\
- largely interpersonal, rather \\
than societal, level of study \\
and impact
\end{tabular} & $\frac{\text { Brey \& Søraker, }}{\underline{2009}}$ \\
\hline $\begin{array}{l}\text { Human - robot } \\
\text { interaction }\end{array}$ & $\begin{array}{l}\text { “.... challenging research field at } \\
\text { the intersection of psychology, } \\
\text { cognitive science, social sciences, } \\
\text { artificial intelligence, computer } \\
\text { science, robotics, engineering and } \\
\text { human-computer interaction. A } \\
\text { primary goal of research in this area } \\
\text { has been to investigate 'natural' } \\
\text { means by which a human can }\end{array}$ & $\begin{array}{l}\text { - focuses on the } \\
\text { relationality of humans and } \\
\text { robots } \\
\text { - incorporates research } \\
\text { from multiple perspectives } \\
\text { and disciplines } \\
\text { - definition emphasizes } \\
\text { dual nature of interaction } \\
\text { and communication }\end{array}$ & $\begin{array}{l}\text { - less emphasis on ethics or } \\
\text { moral consideration } \\
\text { - largely interpersonal, rather } \\
\text { than societal, level of study } \\
\text { and impact } \\
\text { - practice focuses on } \\
\text { tailoring robots to suit } \\
\text { human needs } \\
\text { - the artificial entity must }\end{array}$ & Dautenhahn, 2007 \\
\hline
\end{tabular}




\begin{tabular}{|l|l|l|l|}
\hline $\begin{array}{l}\text { interact and communicate with a } \\
\text { robot. Due to the embodied nature } \\
\text { of this interaction, where robots and } \\
\text { humans need to coordinate their } \\
\text { activities in time and space in real- } \\
\text { time, often 'face-to-face', the } \\
\text { quality of these interactions is } \\
\text { related to, but different from e.g. } \\
\text { human-computer interaction } \\
\text { (HCI)." }\end{array}$ & $\begin{array}{l}\text { have a robotic body or } \\
\text { material structure that can } \\
\text { sense and act on the world }\end{array}$ & \\
\hline
\end{tabular}




\section{References}

American Psychological Association. (2021). Intellect. In APA dictionary of psychology. https://dictionary.apa.org/intellect

American Psychological Association. (2021). Mind. In APA dictionary of psychology. https://dictionary.apa.org/mind

American Psychological Association. (2021). Target. In APA dictionary of psychology. https://dictionary.apa.org/target

Anderson, M., \& Anderson, S.L. (2007). Machine ethics: Creating am ethical intelligent agent. AI Magazine, 28(4), 15-26. https://doi.org/10.1609/aimag.v28i4.2065

Anthis, J.R. (2018, June 21). What is sentience? Sentience Institute. https://www.sentienceinstitute.org/blog/what-is-sentience

Awad, E., Dsouza, S., Kim, R., Schulz, J., Henrich, J., Shariff, A., Bonnefon, J-F., \& Rahwan, I. (2018). The Moral Machine experiment. Nature, 563, 59-64. https://doi.org/10.1038/s41586-018-0637-6

Blascovich, J., \& Ginsburg, G.P. (1978). Conceptual analysis of risk-taking in 'Risky-Shift' research. Journal for the Theory of Social Behaviour, 8(2), 217-230. https://doi.org/10.1111/j.1468-5914.1978.tb00400.x

Block, N. (1995). On a confusion about a function of consciousness. Behavioral and Brain Sciences, 18(2), 227-247. https://doi.org/10.1017/S0140525X00038188

Bostrom, N. (1998). How long before superintelligence?. International Journal of Futures Studies, 2.

Bostrom, N., Dafoe, A., \& Flynn, C. (2020). Public policy and superintelligent AI: A vector field approach. In Liao, S.M. (Ed.), Ethics of artificial intelligence. Oxford Scholarship Online. https://doi.org/ 10.1093/oso/9780190905033.003.0011

Brey, P., \& Søraker, J.H. (2009). Philosophy of computing and information technology. In A. Meijers (Ed.), Philosophy of technology and engineering sciences: A handbook of the philosophy of science (pp. 1341-1407). https://doi.org/10.1016/B978-0-444-516671.50051-3

Broom, D.M. (2020). Brain complexity, sentience and welfare. Animal Sentience, 29(27). https://doi.org/10.51291/2377-7478.1613

Bryson, J.J. (2010). Robots should be slaves. In Y. Wilks (Ed.), Close engagements with artificial companions: Key social, psychological, ethical and design issues (pp. 63-74). John Benjamins Publishing Company.

Bynum, T.W. (2004). Ethics and the information revolution. In R.A. Spinello, \& H.T. Tavani (Eds.), Readings in cyberethics (2nd ed.) (pp. 13-29). Jones and Bartlett Publishers.

Cervantes, J-A., López, S., Rodríguez, L-F., Cervantes, S., Cervantes, F., \& Ramos, F. (2020). Artificial moral agents: A survey of the current status. Science and Engineering Ethics, 26, 501-532. https://doi.org/10.1007/s11948-019-00151-x

Darling, K. (2016). Extending legal protection to social robots: The effects of 
anthropomorphism, empathy, and violent behavior towards robotic objects. In R. Calo, A.M. Froomkin, \& I. Kerr (Eds.), Robot law (pp. 213-232). Elgaronline. https://doi.org/10.4337/9781783476732.00017

Dautenhahn, K. (2007). Methodology \& themes of human-robot interaction: A growing research field. International Journal of Advanced Robotic Systems, 4(1), 103-108. https://doi.org/10.5772/5702

de Graaf, M.M.A, Hindriks, F.A., \& Hindriks, K.V. (2021). Who wants to grant robots rights? In HRI '21 Companion: Companion of the 2021 ACM/IEEE International Conference on Human-Robot Interaction. Association for Computing Machinery. https://doi.org/10.1145/3434074.3446911

DeGrazia, D. (1996). Taking animals seriously: Moral life and moral status. Cambridge University Press. https://doi.org/10.1017/CBO9781139172967

Effective Altruism Forum. (2021). Digital person [Online forum post]. Effective Altruism. https://forum.effectivealtruism.org/tag/digital-person

Floridi, L., \& Sanders, J.W. (2004). On the morality of artificial agents. Minds and Machines, 14, 349-379. https://doi.org/10.1023/B:MIND.0000035461.63578.9d

Fröding, B., \& Peterson, M. (2020). Friendly AI. Ethics and Information Technology. https://doi.org/10.1007/s10676-020-09556-w

Gilbert, M., \& Martin, D. (2021). In search of the moral status of AI: Why sentience is a strong argument. AI \& Society. https://doi.org/10.1007/s00146-021-01179-z

Goertzel, B., \& Pennachin, C. (Eds.). (2007). Artificial general intelligence. Springer.

Gray, H.M., Gray, K., \& Wegner, D.M. (2007). Dimensions of Mind Perception. Science, 315(5812), 619-619. https://doi.org/10.1126/science.1134475

Gray, K., Young, L., \& Waytz, A. (2012). Mind Perception is the essence of morality. Psychological Inquiry, 23(2), 101-124. https://doi.org/10.1080/1047840X.2012.651387

Graziano, M.S.A. (2017). The attention schema theory: A foundation for engineering artificial consciousness. Frontiers in Robotics and AI, 4, 60. https://doi.org/10.3389/frobt.2017.00060

Gunkel, D.J. (2018). Robot rights. MIT Press.

Gunn, L.J., Chapeau-Blondeau, F., McDonnell, M.D., Davis, B.R., Allison, A., \& Abbott, D. (2016). Too good to be true: When overwhelming evidence fails to convince. Proceedings of the Royal Society A, 472(2187), 1-15. https://doi.org/10.1098/rspa.2015.0748

Harris, J. (2021, February 26). The importance of artificial sentience. Sentience Institute. https://www.sentienceinstitute.org/blog/the-importance-of-artificial-sentience

Harris, J., \& Anthis, J.R. (2021) The moral consideration of artificial entities: A literature review. Science and Engineering Ethics, 27(53), 1-95. https://doi.org/10.1007/s11948021-00331-8

Haslam, N. (2016). Concept creep: Psychology's expanding concepts of harm and pathology. Psychological Inquiry, 27(1). https://doi.org/10.1080/1047840X.2016.1082418 
Haslam, N., \& Loughnan, S. (2014). Dehumanization and infrahumanization. Annual Review of Psychology, 65, 399-423. https://doi.org/10.1146/annurev-psych-010213-115045

Himma, K.E. (2009). Artificial agency, consciousness, and the criteria for moral agency: what properties must an artificial agent have to be a moral agent?. Ethics and Information Technology, 11, 19-29. https://doi.org/10.1007/s10676-008-9167-5

Hunt, E. (1995). The role of intelligence in modern society. American Scientist, 83(4), 356-368. https://www.jstor.org/stable/29775483

Jones, M., Harmon, S. \& O'Grady-Jones, M. (2004). Educating the digital mind: Challenges and solutions. In R. Ferdig, C. Crawford, R. Carlsen, N. Davis, J. Price, R. Weber \& D. Willis (Eds.), Proceedings of SITE 2004--Society for Information Technology \& Teacher Education International Conference (pp. 1753-1760). Atlanta, GA, USA: Association for the Advancement of Computing in Education (AACE). https://www.learntechlib.org/primary/p/14684/.

Karnofsky, H. (2016, May 6). Some background on our views regarding advanced artificial intelligence. Open Philanthropy. https:/www.openphilanthropy.org/blog/somebackground-our-views-regarding-advanced-artificial-intelligence

Karnofsky, H. (2021, July 27). Digital people would be an even bigger deal. Cold Takes. https://www.cold-takes.com/how-digital-people-could-change-the-world/

Keller, H. (2016). Psychological autonomy and hierarchical relatedness as organizers of developmental pathways. Philosophical Transactions of the Royal Society B, 371(1686), 1-9. https://doi.org/10.1098/rstb.2015.0070

Körner, A., Topolinski, S., \& Fritz, S. (2015). Routes to embodiment. Frontiers in Psychology, 6, 940. https://doi.org/10.3389/fpsyg.2015.00940

Law Insider. (2021). Artificial entity. In Law insider. https://www.lawinsider.com/dictionary/artificial-entity

Lin, P., Abney, K., \& Bekey, G.A. (Eds.). (2011). Robot ethics: The ethical and social implications of robotics. MIT Press.

Lin, P., Abney, K., \& Bekey, G.A. (2011). Robot ethics: Mapping the issues for a mechanized world. Artificial Intelligence, 175(5-6), 942-949. https://doi.org/10.1016/j.artint.2010.11.026

Lo, S. (2019, June 25). What is a legal person? Law dictionary corrects decades-old error. Nonhuman Rights Blog. https://www.nonhumanrights.org/blog/legal-person-blacks-lawcorrection/

Oxford Languages. (2021). Oxford Languages and Google. Oxford Languages. https://languages.oup.com/google-dictionary-en/

Oxford Reference. (2021). Artificial person. In A dictionary of accounting. https://www.oxfordreference.com/view/10.1093/oi/authority.20110803095426978

Markusen, A. (2003). Fuzzy concepts, scanty evidence, policy distance: The case for rigour and policy relevance in critical regional studies. Regional Studies, 37(6-7), 701-717. https://doi.org/10.1080/0034340032000108796 
Martela, F., \& Riekki, T.J.J. (2018). Autonomy, competence, relatedness, and beneficence: A multicultural comparison of the four pathways to meaningful work. Frontiers in Psychology, 9, 1157. https://doi.org/10.3389/fpsyg.2018.01157

Merriam-Webster. (2021). Being. In Merriam-Webster. https://www.merriamwebster.com/dictionary/being

Mindell, D.A. (2004). Between human and machine: Feedback, control, and computing before cybernetics. Johns Hopkins University Press.

Mobus, G.E. (2019, May 16). A theory of sapience: Using systems science to understand the nature of wisdom and the human mind. Millennium Alliance for Humanity and the Biosphere. https://mahb.stanford.edu/library-item/theory-sapience-using-systemsscience-understand-nature-wisdom-human-mind/

Molina, M. (2020). What is an intelligent system?. ArXiv. https://arxiv.org/abs/2009.09083

Moor, J.H. (2006). The nature, importance, and difficulty of machine ethics. IEEE Intelligent Systems, 21(4), 18-21. https://doi.org/10.1109/MIS.2006.80.

Muehlhauser, L. (2013, June 19). What is intelligence?. Machine Intelligence Research Institute. https://intelligence.org/2013/06/19/what-is-intelligence-2/

Muehlhauser, L. (2017, June). 2017 Report on consciousness and moral patienthood. Open Philanthropy. https://www.openphilanthropy.org/2017-report-consciousness-and-moralpatienthood

Oliveira, A. (2017). The digital mind: How science is redefining humanity. MIT Press.

Reggia, J.A. (2013). The rise of machine consciousness: Studying consciousness with computational models. Neural Networks, 44, 112-131. https://doi.org/10.1016/j.neunet.2013.03.011

Reisman, J.M. (1984). Friendliness and its correlates. Journal of Social and Clinical Psychology, 2(2), 143-155. https://doi.org/10.1521/jscp.1984.2.2.143

Russell, S., \& Norvig, P. (1995). Artificial intelligence: A modern approach (1st ed.). Prentice Hall.

Scheutz, M. (2013). What is robot ethics? [TC Spotlight]. IEEE Robotics \& Automation Magazine, 20(4), 20. https://doi.org/10.1109/MRA.2013.2283184.

Shepherd, J., \& Levy, N. (2020). Consciousness and morality. In Y. Kriegel (Ed.), The Oxford handbook of the philosophy of consciousness. Oxford Handbooks Online. https://doi.org/10.1093/oxfordhb/9780198749677.013.30

Shulman, C., \& Bostrom, N. (2021). Sharing the world with digital minds. In S. Clarke, H. Zohny, \& J. Savulescu (Eds.), Rethinking moral status. Oxford Scholarship Online. https://doi.org/10.1093/oso/9780192894076.001.0001

Silverio-Fernández, M., Renukappa, S., \& Suresh, S. (2018). What is a smart device? - a conceptualisation within the paradigm of the internet of things. Visualization in Engineering, 6(3), 1-10. https://doi.org/10.1186/s40327-018-0063-8

Sotala, K. (2012). Advantages of artificial intelligences, uploads, and digital minds. International 
Journal of Machine Consciousness, 4(1), 275-291.

https://doi.org/10.1142/S1793843012400161

Spring, J. (2012). Education networks: Power, wealth, cyberspace, and the digital mind. Routledge. https://doi.org/10.4324/9780203156803

Stanford Encyclopedia of Philosophy. (2014). Consciousness. In Stanford encyclopedia of philosophy. https://plato.stanford.edu/entries/consciousness/

Stanford Encyclopedia of Philosophy. (2019). Eliminative materialism. In Stanford encyclopedia of philosophy. https://plato.stanford.edu/entries/materialism-eliminative/

Stanford Encyclopedia of Philosophy. (2020). Machine ethics. In Stanford encyclopedia of philosophy. https://plato.stanford.edu/entries/ethics-ai/\#MachEthi

Stanford Encyclopedia of Philosophy. (2020). The definition of morality. In Stanford encyclopedia of philosophy. https://plato.stanford.edu/entries/morality-definition/

Stanford Encyclopedia of Philosophy. (2021). Qualia. In Stanford encyclopedia of philosophy. https://plato.stanford.edu/entries/qualia/

Stephan, W.G., Ybarra, O., \& Morrison, K.R. (2009). Intergroup threat theory. In T.D. Nelson (Ed.), Handbook of prejudice, stereotyping, and discrimination (pp. 43-59). Psychology Press.

Sternberg R.J. (1986). A triarchic theory of human intelligence. In S.E. Newstead, S.H. Irvine, \& P.L. Dann (Eds.), Human assessment: Cognition and motivation. Springer. https://doi.org/10.1007/978-94-009-4406-0_9

Velasquez, M., Andre, C., Shanks, T., \& Meyer, M.J. (2010, January 1). What is ethics?. Markkula Center for Applied Ethics. https://www.scu.edu/ethics/ethics-resources/ethicaldecision-making/what-is-ethics/

Weiss, L.G., Saklofske, D.H., Holdnack, J.A., Prifitera, A. (2019). WISC-V: Clinical use and interpretation (2nd ed.). Academic Press. https://doi.org/10.1016/C2017-0-03528-0

Wiblin, R. (Host). (2020, July 9). Ben Garfinkel on scrutinising classic AI risk arguments (No. 81) [Audio podcast episode]. In The 80,000 Hours Podcast. 80,000 Hours. https://80000hours.org/podcast/episodes/ben-garfinkel-classic-ai-risk-arguments/

Wiener, N. (1948). Cybernetics; or control and communication in the animal and the machine. John Wiley.

\section{Acknowledgments}

Many thanks to Jacy Reese Anthis, Ali Ladak, Thomas Moynihan, Tobias Baumann, and Teo Ajantaival for reviewing and providing feedback. 